\title{
A unified hydrogeological conceptual model of the Milk River transboundary aquifer, traversing Alberta (Canada) and Montana (USA)
}

\author{
Marie-Amélie Pétré $^{1,2}$ - Alfonso Rivera ${ }^{1} \cdot$ René Lefebvre $^{2} \cdot$ M. Jim Hendry ${ }^{3}$. \\ Attila J. B. Folnagy ${ }^{4}$
}

Received: 21 December 2015 / Accepted: 25 May 2016 / Published online: 29 June 2016

(C) The Author(s) 2016. This article is published with open access at Springerlink.com

\begin{abstract}
A conceptual model of the transboundary Milk River Aquifer (MRA), extending across the Canada-USA border, was developed based on literature, focused fieldwork and a three-dimensional geological model. The MRA corresponds to the Virgelle Member of the Milk River Formation (Eagle Formation in Montana, USA) and it is an important groundwater resource over a large area $\left(25,000 \mathrm{~km}^{2}\right)$. The Virgelle outcrops near the international border and along the Sweet Grass Arch in Montana. The down-gradient limit of the MRA is the unconformity separating the Virgelle from the gasbearing sandy shale of the Alderson Member. The MRA is confined above by the Pakowki/Claggett Formations aquitards and below by the Colorado Group aquitard. The MRA contains higher transmissivity areas resulting in preferential flowpaths, confirmed by natural geochemical tracers. Tritium and ${ }^{14} \mathrm{C}$ delineate restricted recharge areas along the outcrops on both sides of the international
\end{abstract}

Electronic supplementary material The online version of this article (doi:10.1007/s10040-016-1433-8) contains supplementary material, which is available to authorized users.

Marie-Amélie Pétré

marie-amelie.petre@ete.inrs.ca

1 Geological Survey of Canada, Québec Division, 490 rue de la Couronne, Québec G1K 9A9, QC, Canada

2 INRS Centre Eau Terre Environnement, 490 rue de la Couronne, Québec G1K 9A9, QC, Canada

3 Department of Geological Sciences, University of Saskatchewan, Geology Building, 114 Science Place, S7N 5E2 Saskatoon, SK, Canada

4 Montana Department of Natural Resources and Conservation, Water Management Bureau, 1424 9th Avenue, Helena, MT 59620, USA border. Drastic decreases in horizontal hydraulic gradients indicate that the Milk River intercepts a large proportion of groundwater flowing to the north from the recharge area. Downgradient of the Milk River, groundwater movement is slow, as shown by ${ }^{36} \mathrm{Cl}$ residence times exceeding $1 \mathrm{Ma}$. These slow velocities imply that groundwater discharge downgradient of the Milk River is via vertical leakage through the Colorado Group and upward along buried valleys, which act as drains and correspond to artesian areas. When confined, the MRA contains a fossil groundwater resource, not significantly renewed by modern recharge. Groundwater exploitation thus far exceeds recharge, a situation requiring properly managed MRA groundwater depletion.

Keywords Transboundary aquifer $\cdot$ Conceptual model $\cdot$ Milk River aquifer · Canada $\cdot$ USA

\section{Introduction}

It is estimated that there are about 366 transboundary aquifers worldwide (IGRAC 2015). The sound management of these shared groundwater resources is an important issue, especially in arid and semi-arid climates. Management of this resource requires a detailed understanding of the aquifer dynamics along its natural hydrogeological boundaries. Quantification of groundwater fluxes in the aquifer can be determined using groundwater numerical models. The foundation of these numerical models is the hydrogeological conceptual model (Bredehoeft 2005). Kresik and Mikszewski (2012) define the hydrogeological conceptual model as "the description of various natural and anthropogenic factors that govern and contribute to the movement of groundwater in the subsurface". 
The objective of the present study was to develop a hydrogeological conceptual model of the transboundary Milk River Aquifer (MRA). The MRA spans parts of southern Alberta (Canada) and northern Montana (USA), in a semi-arid region considered water-short (Government of Alberta 2006). The hydrogeological transboundary extent of the MRA is about $25,000 \mathrm{~km}^{2}$. The MRA consists of the Virgelle Member of the Upper Cretaceous Milk River Formation in Alberta, which corresponds to the Eagle Formation in Montana. This aquifer has been a primary resource for livestock watering, secondary oil recovery and domestic uses in the study area. It has been extensively used during the 20th century, locally causing a drop (up to $30 \mathrm{~m}$ ) in water levels or a decrease in flow rate (AGRA Earth and Environmental 1998). Since the mid-1950s, concerns about the sustainability and the "mismanagement" of the resource have been raised, notably by Meyboom (1960) and Borneuf (1976). From 1999 to 2004, a MRA conservation program was established in southern Alberta. It followed the AGRA Earth and Environmental (1998) depletion study of the MRA. Groundwater from the MRA is still being actively used on both sides of the Canada USA border, with no allocation sharing agreement. The MRA has been intensively studied over the last century; however, most of these studies did not extend across the Canada-USA border (Meyboom 1960; Zimmerman 1967; Schwartz and Muehlenbachs 1979; Hendry et al. 1991; Alberta Innovates Technology Futures 2010), thus preventing an understanding of the full aquifer dynamics. A comprehensive representation of the aquifer is required to evaluate the conditions needed for its sound management on both sides of the border.

Prior to generating a conceptual model of the aquifer system, a common stratigraphic framework and a 3D unified geological model in which the hydrostratigraphic units are defined were required. These were generated by Pétré et al. (2015; Fig. 1). In the current study, the hydrogeological conceptual model of the aquifer system is developed within its complete natural extent (Fig. 1) by linking hydrogeological and geochemical data with the 3D unified geological model. This study is based on a thorough literature review and focused complementary fieldwork, documented by Pétré and Rivera (2015). The comprehensive approach that is used in this study can be applied in other characterization and quantification studies of regional aquifers.

\section{Study area and Milk River Aquifer extent}

The study area is located in the south-western part of the Plains Hydrogeological Region (Grasby et al. 2014). It ranges from longitude -110.0 to $-112.5^{\circ}$ and from latitude 48.2 to $50.0^{\circ}$. The MRA spans southern Alberta and

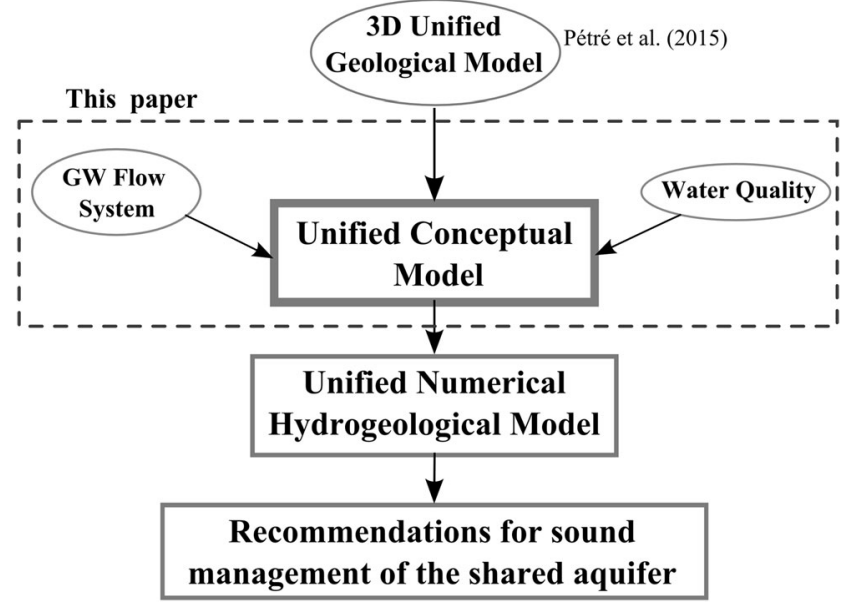

Fig. 1 Successive stages of the MRA study. This paper addresses the second step - the development of a unified hydrogeological conceptual model of the aquifer system

northern Montana, which has a semi-arid climate with mean annual precipitation between 250 and $450 \mathrm{~mm} / \mathrm{y}$ and potential evapotranspiration (ET) ranging from 550 to $578 \mathrm{~mm} / \mathrm{y}$ (Climate Canada 2015; NOAA 2015). The topography of the region is undulating to hummocky and the main topographic highs are the Sweet Grass Hills, the Cypress Hills, the Milk River Ridge and the Bears Paw Mountains (Fig. 2). The main geological feature in the study area is the Sweet Grass Arch, composed of the Kevin Sunburst Dome, the Sweet Grass Hills and the Bow Island Arch. The hydrography of the region includes the transboundary Milk River, Pakowki Lake and a number of intermittent channels (e.g., Etzikom, Chin and Forty Mile coulees). The coulees are meltwater channels formed by glacial erosion or by the continuing erosion of water and wind (Dormaar 2010). The Milk River originates in northwest Montana and flows northward into Alberta; it loops eastward through the town of Milk River and then returns southward to Montana. The Milk River flow is artificially increased from about 1 to $16 \mathrm{~m}^{3} / \mathrm{s}$ during the irrigation season via the St. Mary Canal in Montana (MacCulloch and Wagner-Watchel 2010). Pakowki Lake located west of Manyberries, seasonally receives water from the Etzikom Coulee and is $1.2 \mathrm{~m}$ deep on average. The lake covers up to $123 \mathrm{~km}^{2}$; however, it was mostly dry during the 1980s and began to refill in the early 1990s (Sosiak and Branch 1997). In the Sweet Grass Hills area, the streams are mostly intermittent (Dormaar 2003). Streams flow from the north side of the Sweet Grass Hills into the Milk River, and from the south side into the Marias River.

Buried valleys (bedrock channels) are present across the study area (Fig. 2). These buried valleys are preglacial stream valleys buried by glacial drift (Cummings et al. 2012). The Medicine Hat, Skiff and Foremost buried valleys are up to $10 \mathrm{~km}$ wide and are incised up to $30 \mathrm{~m}$ 

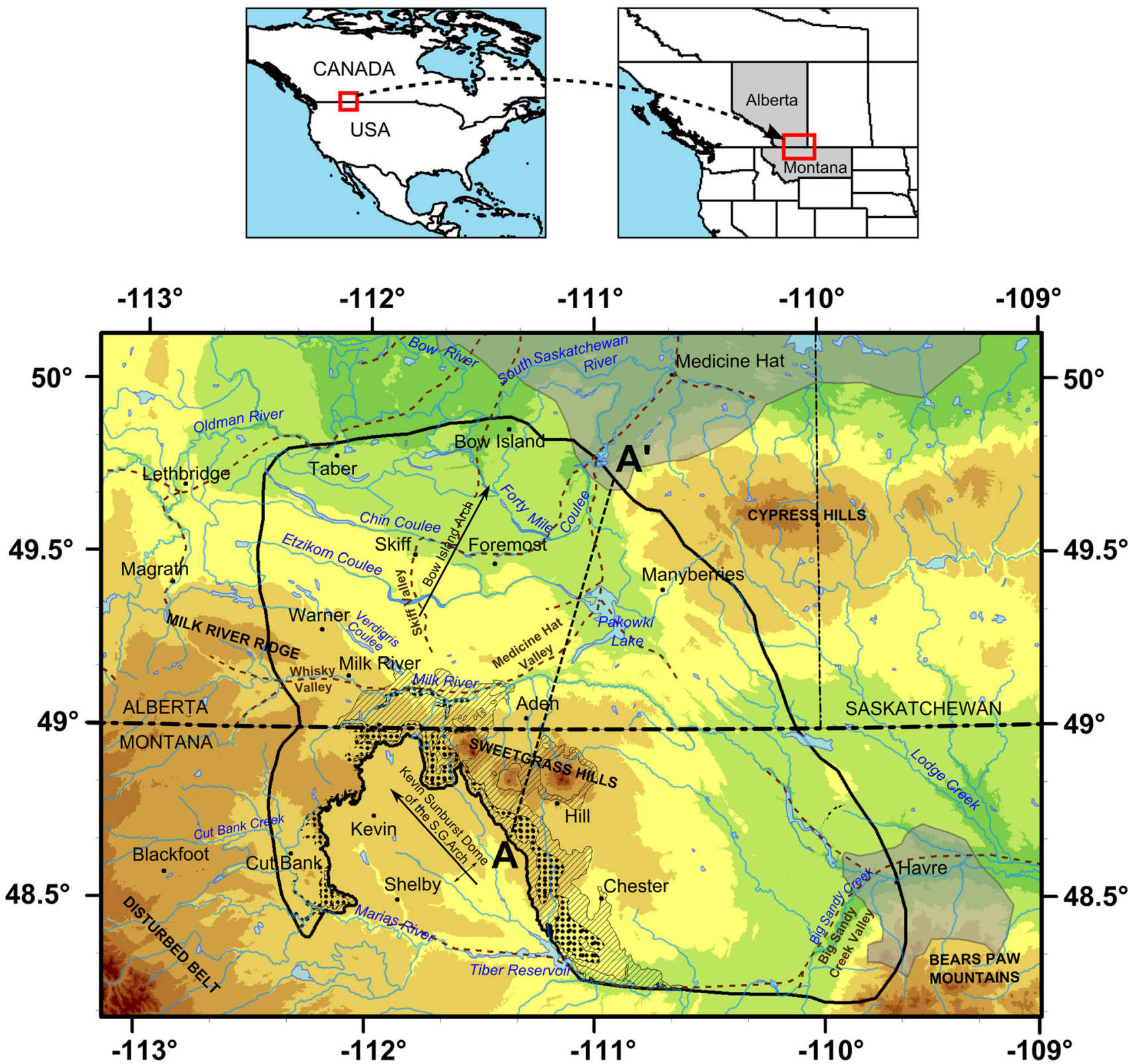

\section{Legend}

Topography elevation (m.a.s.I.)

$\square$ Hydrogeological extent of the Milk River Aquifer

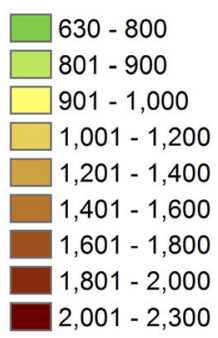

Milk River Formation outcrop area (modified from Okulitch et al. (1996))

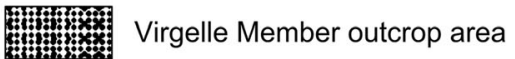

$2,001-2,300$

TIIIIII Telegraph Creek and Deadhorse Coulee Members outcrop area

Fig. 2 Study area, topography elevation and extent of the MRA. S.G. Arch stands for Sweet Grass Arch

into bedrock (Hendry and Buckland 1990; HCL consultants 2004), which is generally comprised of the
Belly River Formation or Pakowki Formation in the study area. In Montana, well logs examination (GWIC ID Nos. 
$163464,3502,40420,40433)$ and the geological map from Lopez (2002) suggest that the ancestral Missouri River buried valley in the Big Sandy Creek drainage is up to $5 \mathrm{~km}$ wide and is incised up to $75 \mathrm{~m}$ into bedrock.

Boundaries of the conceptual model of the MRA follow the natural hydrogeological extent of the MRA (Fig. 2). The hydrogeological limits of the MRA include the Virgelle Member (middle member of the Milk River Formation) and the groundwater-bearing Upper Alderson Sands, located along the depositional limit of the Virgelle Member (Pétré et al. 2015). The northern limit of the model corresponds to the southern edge of the Medicine Hat gas field in Alberta. The south-eastern limit is the Tiger Ridge gas field, located in the Bears Paw Mountains. These gas fields are natural limits of the MRA; more details can be found elsewhere (Rice and Claypool 1981; Berkenpas 1991; Anna 2011; Chen et al. 2015). For the purpose of this paper, the southern limit is constituted by the Marias River in Montana, although the MRA may extend beyond this limit.

\section{Methods}

Hydrogeological and geochemical data from various sources were compiled and underwent some processing to have a unified unit and coordinate system. New data were added from the three field studies carried out as part of the Geological Survey of Canada's MiRTAP (Milk River Transboundary Aquifer Project; Rivera 2011). The field campaigns took place in winter 2012 (Alberta), summer 2013 (Montana) and winter 2013 (Alberta). The objectives of these field studies were to: (1) measure static water levels from private wells completed in the MRA; (2) collect groundwater samples for isotopic analyses $\left({ }^{3} \mathrm{H},{ }^{13} \mathrm{C},{ }^{14} \mathrm{C}\right.$ and $\left.{ }^{36} \mathrm{Cl}\right)$; (3) measure the pressure of flowing artesian wells; and (4) conduct a survey with landowners and municipalities regarding current groundwater use.

Fifteen static water levels were measured over the study area. Four pressure measurements were obtained from flowing artesian wells in southern Alberta (Fig. 7). Twenty-three groundwater samples were collected and analysed for ${ }^{3} \mathrm{H},{ }^{13} \mathrm{C}$ and ${ }^{14} \mathrm{C}$ (12 in Alberta and 11 in Montana) by the University of Waterloo Environmental Isotopes Laboratory (EILAB, Waterloo, Ontario). ${ }^{36} \mathrm{Cl}$ analyses were performed on 20 groundwater samples (9 in Alberta and 11 in Montana). The ${ }^{36} \mathrm{Cl}$ samples from Alberta were analysed by the PRIME Lab (Purdue University, Indiana, USA) and those from Montana by the Center for AMS (Livermore, California, USA). Inorganic chemistry analyses were also done for the 11 Montana samples by the INRS lab (Québec, Canada). The groundwater samples are all representative of the
MRA. The transboundary data from the MiRTAP project will be available before the end of 2016 through the Groundwater Information Network (GIN 2015) of NRCan and Montana's Ground Water Information Center database (GWIC 2015).

\section{Groundwater use}

The MRA has represented an important water resource for the region for about a century, which is still the case today, especially given the semi-arid climate of the study area and its relatively high threat to surface water availability (Environment and Climate Change Canada 2012). The development of the MRA started around 1915 in southern Alberta and increased over the 20th century. In southern Alberta, the number of wells increased from 409 in 1960 to 1,027 in the early 2000s (Meyboom 1960; Printz 2004). As a result, the total groundwater use almost doubled between 1960 and the early $1990 \mathrm{~s}$, from $1.2 \times 10^{6}$ - (Meyboom 1960) to $2.0 \times$ $10^{6} \mathrm{~m}^{3} / \mathrm{y}$ (Persram, Alberta Environmental Protection, Hydrogeology Branch, unpublished report, 1992, cited by AGRA Earth and Environmental (1998) (Fig. 3). This rise is mostly due to the increase in the number of livestock. Since the mid-1990s groundwater use has declined. Recent reports have estimated a total consumption of $1.2 \times 10^{6} \mathrm{~m}^{3} / \mathrm{y}$, which is close to the 1960 value (Stantec 2002; HCL consultants 2004, 2007). From Fig. 3, the cumulative use was estimated to $111.8 \times 10^{6} \mathrm{~m}^{3}$ in southern Alberta, assuming that the evolution of the consumptive use is linear between 1915 and 2005, and remains constant between 2005 and 2015.

Since the 1960s, many wells have lost their artesian flow condition because of the intensive use of the MRA. Water levels dropped mostly in the central part of the aquifer, where the largest users are present (Meyboom 1960; AGRA Earth and Environmental 1998). An observation well near Foremost, Alberta, which obtains its water from three municipal wells, shows a water level decrease of more than $45 \mathrm{~m}$ between 1957 and 2006 (Fig. 4). Such a continuous water level drawdown is usually considered as an adverse consequence of aquifer development (Custodio 2002). The other four MRA observation wells located in southern Alberta do not show as steep of a declining water level trend as in Foremost (Pétré and Rivera 2015). These observation wells may not be ideally located to reflect the general drop of the water level shown from the comparison of the 1960 and 1998 potentiometric surface maps (AGRA Earth and Environmental 1998).

Furthermore, many artesian wells in southern Alberta were allowed to flow freely at the surface for decades. This volume of unused water, also termed "water wastage" by Meyboom (1960) was $0.3 \times 10^{6} \mathrm{~m}^{3} / \mathrm{y}$. Borneuf (1976) termed this a "mismanagement" of the resource. The amount of water wastage was decreased during the recent MRA Conservation Program 
Fig. 3 Total estimated groundwater use from the MRA in southern Alberta, Canada

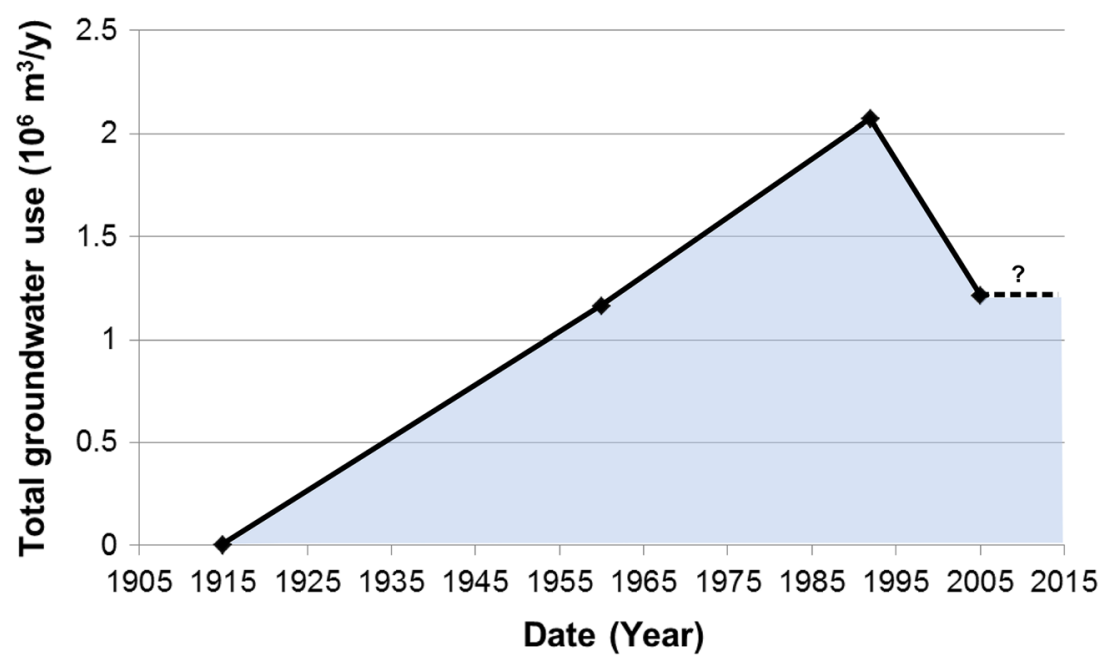

(Printz 2004) during which 22 flowing wells were cemented, resulting in approximately $60,000 \mathrm{~m}^{3} / \mathrm{y}$ of water savings. The recent survey conducted with municipalities as part of the current study indicates a generally decreasing use, as a result of population decline in the study area and connection to the regional water pipeline. The complete results of the groundwater use survey conducted with municipalities are presented as electronic supplementary material (see Table S1 in the ESM).

In Montana, groundwater use data are limited due to the lack of statutory requirement for water rights holders to measure their diverted volume. West of the Sweet Grass Arch, in the Cut Bank area, groundwater from the Virgelle Member and the Two Medicine Formation are the main sources of fresh water for domestic, stock and industrial use (Zimmerman 1967). The recent survey indicates that rural residents from several municipalities as well as oil refineries still depend on groundwater supplies.

The total groundwater in the Cut Bank area was estimated by Zimmerman (1967) to be about $1.6 \times 10^{6} \mathrm{~m}^{3} / \mathrm{y}$. In the Sweet Grass Hills area, Tuck (1993) estimates that the Virgelle discharge from wells reached a value of $0.1 \times 10^{6} \mathrm{~m}^{3} / \mathrm{y}$. About $70 \%$ of this flow rate was used for secondary oil recovery and about $21 \%$ correspond to the freely flowing wells (wastage). Secondary oil recovery is still occurring in the Sweet Grass Hills area but water use records for supply wells from the MRA are lacking. In the vicinity of the gas fields both in Alberta and Montana, the production of

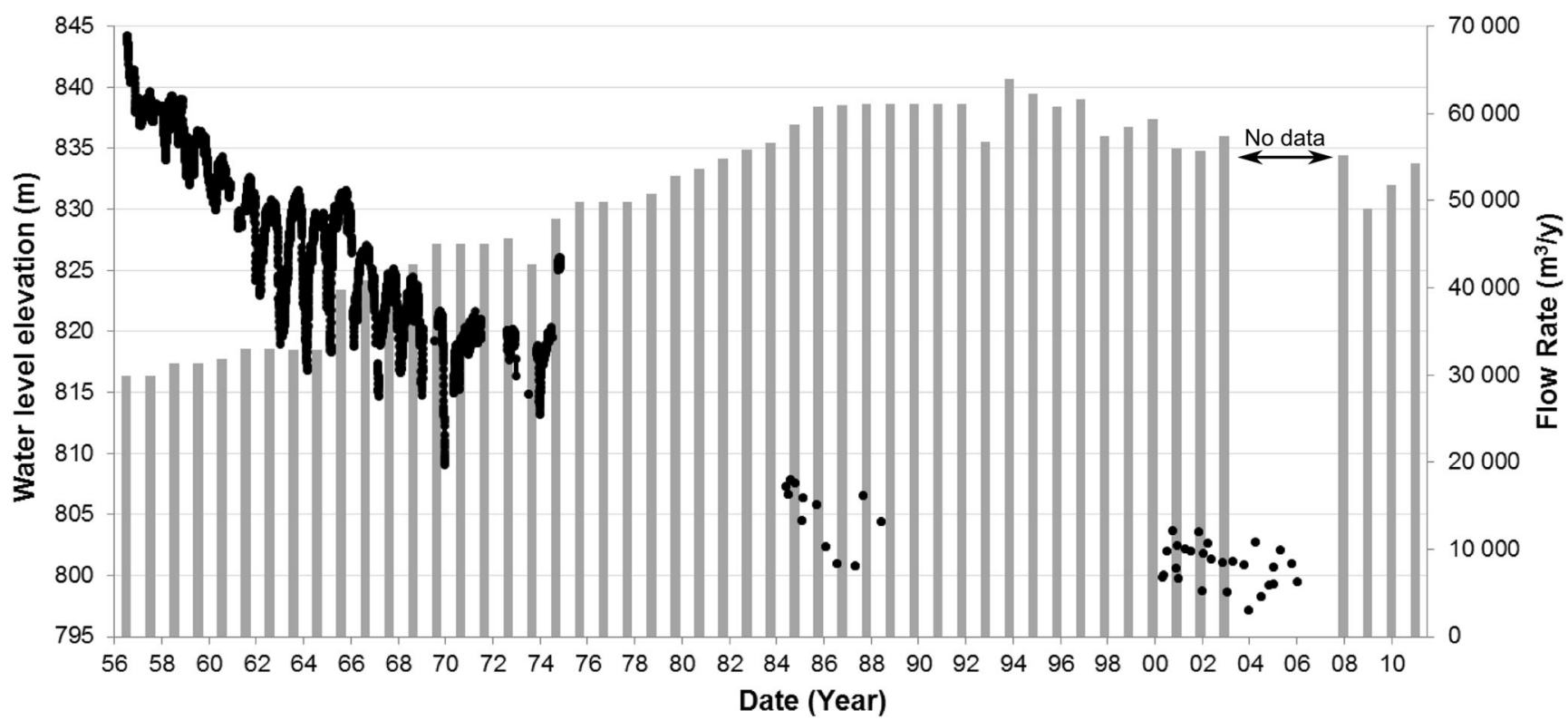

Fig. 4 Water level of the Foremost observation well (AENV ID No. 221; black dots) and annual groundwater diversion (gray bars) for the village of Foremost (HCL consultants 2004; Alberta Environment and Parks 2015) 
water related to gas extraction could influence fluid volumes within the MRA (Berkenpas 1991; MBOGC 2015). Further studies are required to determine precisely the extracted volumes and their effect on the groundwater resource. Monitoring wells in the outcrop/subcrop area of the MRA in Montana as well as the study from Zimmerman (1967) show that water levels are stable during their period of record (Pétré and Rivera 2015). Therefore, concerns about depletion of the MRA are mostly present on the Alberta side of the study area. Some additional work would be required to better define the possible range of exploitation values including sorting and analysing the public water well databases in Alberta and Montana.

\section{Hydrogeological setting}

\section{Hydrostratigraphy}

A geological cross-section through the aquifer system is presented in Fig. 5 (location shown on Fig. 2). Colorado Group underlies the geological units in the study area. It is a $500-\mathrm{m}$ thick regional aquitard and contains several thin sandstone beds, the most significant being the Bow Island Sandstone. The Bow Island Sandstone is about $25 \mathrm{~m}$ thick and is separated from the overlying Milk River Formation by approximately $400 \mathrm{~m}$ of shale (Swanick 1982; Phillips et al. 1986; Hendry and Schwartz 1988).

The Milk River Formation is about $100 \mathrm{~m}$ thick on average and is subdivided into three members. The basal Telegraph Creek Member is a transitional unit between the Colorado Group and the sandstone of the middle member Virgelle. The Virgelle Member constitutes the MRA. The upper member of the Milk River Formation is the low-permeability Deadhorse Coulee Member.

The Milk River Formation not only outcrops or subcrops following continuous and narrow belts on both sides of the Sweet Grass Arch, but also around the Sweet Grass Hills and in southern Alberta near the international border (Fig. 2). The Virgelle Member outcrop is well recognizable west of the Sweet Grass Arch, as it shows many high escarpments (Collier 1930; Zimmerman 1967).

The Milk River Formation is overlain by the Pakowki Formation (Claggett Formation in Montana), which is a 130$\mathrm{m}$-thick aquitard. The Pakowki/Claggett aquitard thins towards the west and north-west in Alberta (Pétré et al. 2015). The Belly River Group (Judith River Formation in Montana) overlies the Pakowki/Claggett Formation (Fig. 5). A detailed description of the stratigraphy and hydrostratigraphy of these Upper Cretaceous units in the study area is provided in Pétré et al. (2015).

The study area is covered by glacial drift, except on the topographic highs (such as the Cypress Hills and the Sweet
Grass Hills) and in the coulees (Williams and Dyer 1930; Colton et al. 1961; Fullerton and Colton 1986; Robertson 1988). As the glacial drift consists mainly of lowpermeability till, the surficial deposits in the study area generally do not constitute productive aquifers (Borneuf 1976; Robertson 1988); however, the buried valleys can form very productive aquifers in southern Alberta (Farvolden et al. 1963). Although the content of the buried valley is generally heterogeneous, making their aquifer potential difficult to predict, the fill material of the buried valleys in the study area is predominantly sand and gravel (HCL consultants 2004; Cummings et al. 2012). The Whisky Valley Aquifer (west of the Town of Milk River) lies in the bottom of the Whisky buried valley. This sand and gravel aquifer is connected to the MRA locally (Golder Associates 2004).

\section{Transmissivity and hydraulic conductivity of the aquifer}

The transmissivity $(T)$ of an aquifer is generally obtained from aquifer tests. It is a fundamental parameter in the characterization of a groundwater resource as well as an important control on groundwater flow. The first transboundary map of the $T$ (in $\mathrm{m}^{2} / \mathrm{s}$ ) of the MRA was produced by compiling $133 \mathrm{~T}$ data points compiled from Meyboom (1960); Persram (Alberta Environmental Protection, Hydrogeology Branch, unpublished report, 1992, cited by AGRA Earth and Environmental 1998); Zimmerman (1967); Tuck (1993); Levings (1981); Norbeck (2006) and Water Right Solutions Inc. (Cool Spring Colony - Application for Beneficial Water Use Hydrogeologic Assessment, submitted for Water Right Permit No. 40G 30045714, 5 pp, unpublished report, 2009). The $T$ data and the spatial distribution of the log $T$ values (interpolated by Empirical Bayesian Kriging in ArcGIS) are shown in Fig. 6. The highest $T$ values are present around the Sweet Grass Hills and in the southwestern part of the aquifer in Montana. Transmissivity values range from $1 \times 10^{-4}$ and $3 \times 10^{-2} \mathrm{~m}^{2} / \mathrm{s}$, west of the Sweet Grass Arch (Zimmerman 1967; Norbeck 2006) and from $2 \times 10^{-4}$ to $4 \times 10^{-3} \mathrm{~m}^{2} / \mathrm{s}$ in the Sweet Grass Hills area (Tuck 1993), whereas in southern Alberta, $T$ ranges from $1 \times 10^{-6}$ to $5 \times 10^{-4} \mathrm{~m}^{2} / \mathrm{s}$ (Meyboom 1960; Persram (Alberta Environmental Protection, Hydrogeology Branch, unpublished report, 1992, cited by AGRA Earth and Environmental 1998). Faulting and fracturing (secondary porosity) around the igneous intrusion of the Sweet Grass Hills have increased the $T$ of the Virgelle Member locally (Tuck 1993). In the south-west corner of the study area, Zimmerman (1967) indicates that the structural deformations may have greatly affected the $T$ of the Virgelle Member, which transmits water mainly through fractured sandstone. 


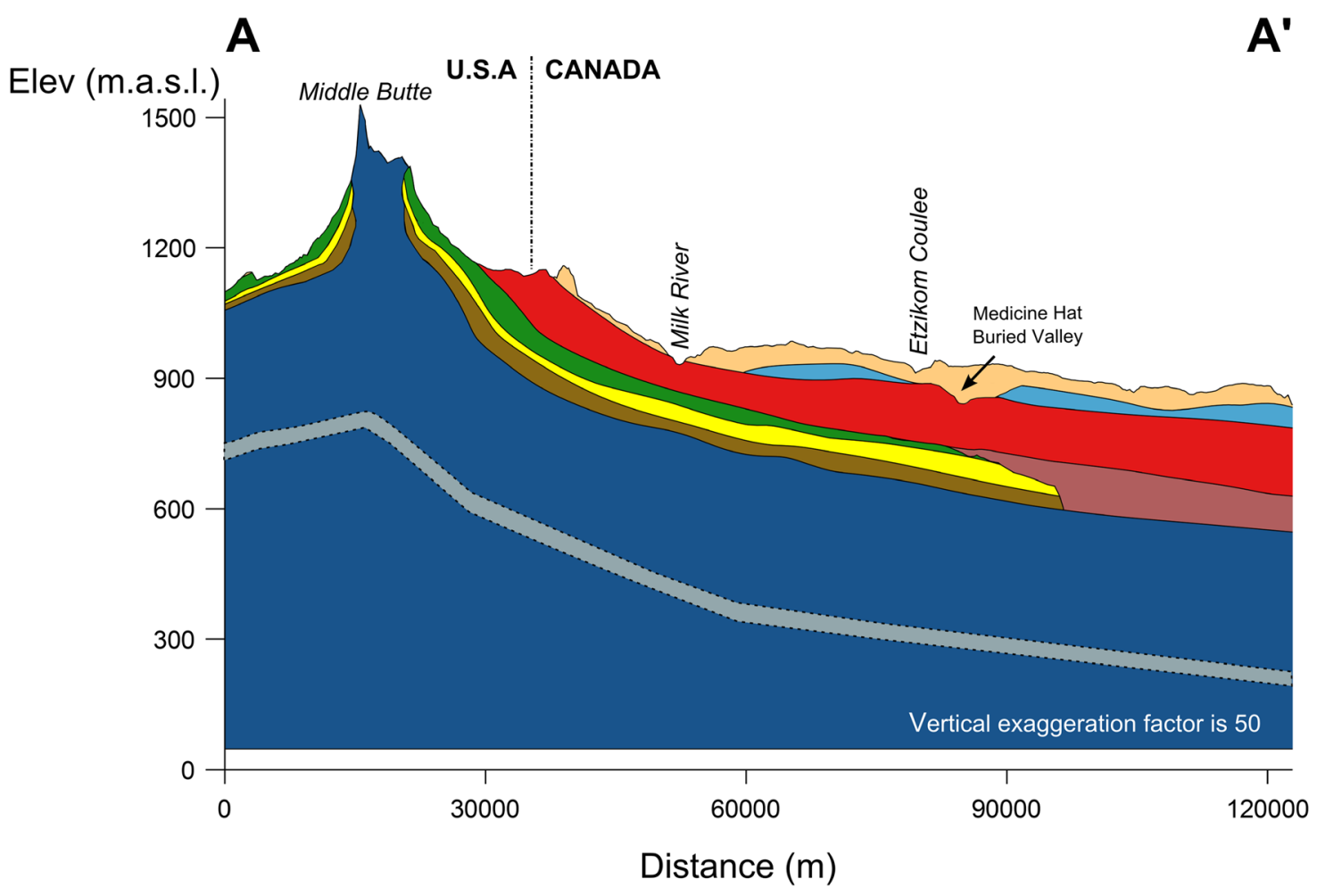

Legend

Bearpaw Formation+ surficial sediments (marine shale and glacial till)

Belly River Group/Judith River Formation (variable lithologies from shale to sandstone)

Claggett Shale/Pakowki Formation (black marine shale)

Upper Alderson Sands of the Alderson Member (sand)

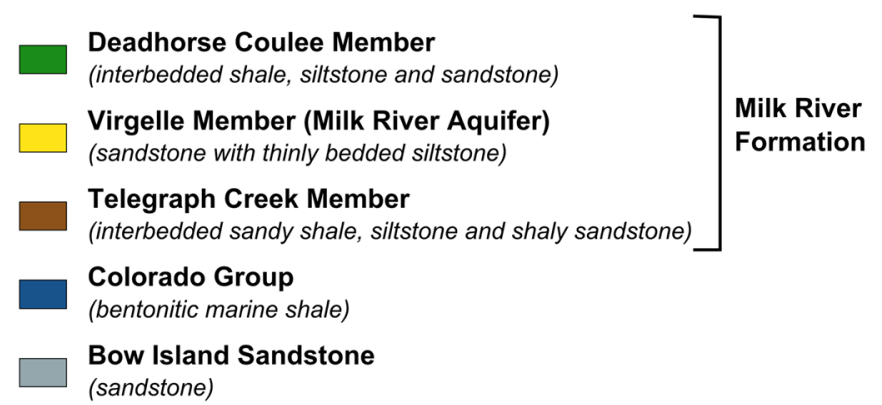

Deadhorse Coulee Member

(interbedded shale, siltstone and sandstone)

Virgelle Member (Milk River Aquifer)

(interbedded sandy shale, siltstone and shaly sandstone)

Colorado Group

(bentonitic marine shale)

(sandstone)

Fig. 5 Geological cross-section of the Milk River Formation and overlying and underlying geologic units. The location of the cross section is shown on Fig. 2

In the south-eastern part of the study area in Montana, east of Chester, the $T$ is low $\left(1 \times 10^{-6} \mathrm{~m}^{2} / \mathrm{s}\right)$. In southern Alberta, a high $T$ zone extends from the USA border, around Aden, to Lake Pakowki and then north near Foremost. An area of low $T$ is located in the central part of the study area, between the towns of Foremost and Skiff. West of this low $T$ area, the $T$ values increase over a limited extent but do not attain values as high as in the east. Figure 6 shows a central low-transmissivity area, surrounded by two corridors of higher transmissivity as previously evoked by AGRA Earth and Environmental (1998).

\section{Potentiometric map, groundwater flow paths and artesian conditions}

Groundwater flow directions in the MRA, recharge and discharge areas can be inferred from the potentiometric surface of the aquifer. Parts of the potentiometric surface of the MRA were mapped by Meyboom (1960); Borneuf (1974); Toth and Corbet (1986) and AGRA Earth and Environmental (1998) in southern Alberta and by Zimmerman (1967); Levings (1982a), and Tuck (1993) in northern Montana.

Based on these historical potentiometric maps, groundwater flow directions were shown on two-dimensional (2D) vertical cross-sections by Pétré et al. (2015). Previous potentiometric maps are all limited by the international border, preventing a complete representation of potentiometric conditions in the aquifer, especially close to the international border.

The first transboundary potentiometric map of the MRA (Fig. 7) was compiled from historical maps from Zimmerman (1967), AGRA Earth and Environmental (1998), Tuck (1993) and Levings (1982a). Four pressure 
Fig. 6 Transboundary map of transmissivity $T$ (kriged from available data points shown on the map) in the MRA

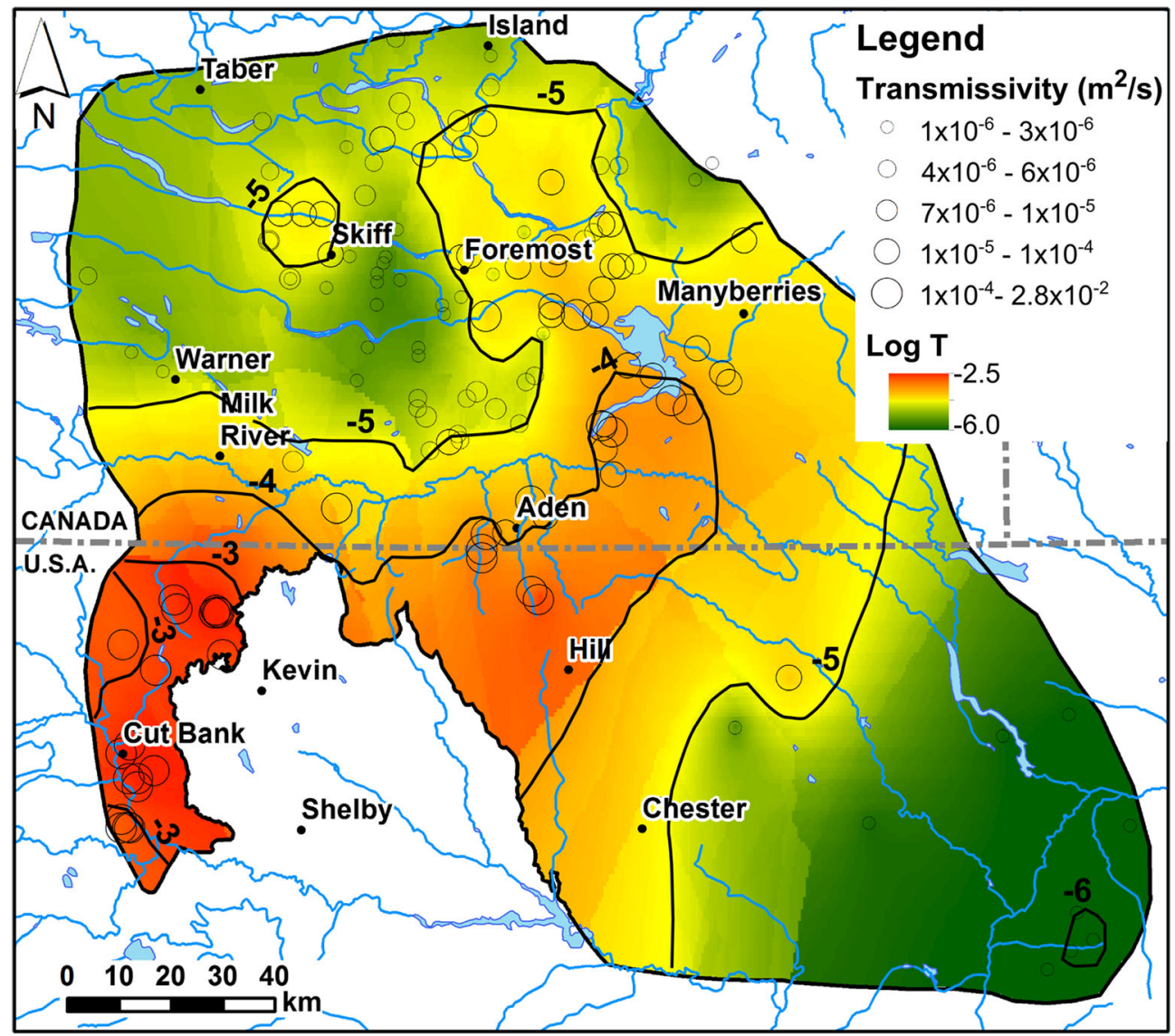

versus depth profiles provided by Berkenpas (1991) were converted to equivalent hydraulic heads and were also used to complete the potentiometric map at the northern and eastern limits of the MRA in Alberta. Efforts were made to harmonize the various datasets, especially at the USA-Canada border, to properly represent the transboundary groundwater flow characteristics of the aquifer. A dataset of 40 recent water level measurements (2006-2014) collected during the MiRTAP fieldwork (20122013), or obtained from public databases - GWIC (2015); Alberta Environment and Parks (2015) — and the Agriculture and Agri-Food Canada, Prairie Farm Rehabilitation Administration monitoring project (PFRA, unpublished report, 2014) was used to validate the transboundary map and confirm the inferred regional groundwater flow patterns.

The highest piezometric heads were measured in the Sweet Grass Hills and in an area north of Cut Bank. These correspond to the recharge areas where the MRA outcrops or subcrops. High piezometric heads were also measured in the area east of Manyberries and in the southeast corner of the study area, indicating a component of groundwater flow laterally from other geological units. This water originates in the Cypress Hills (Toth and Corbet 1986) and the Bears Paw Mountains (Levings 1982a). Piezometric lows are located in the Pakowki Lake area and in the northern part of the study area in Alberta and along Cut Bank Creek and Big Sandy Creek in Montana. Data suggest that these piezometric lows correlate with the talweg of the buried valleys in the study area. The buried valleys may influence outflow of groundwater out of the MRA, as suggested by Borneuf (1976), in southern Alberta. Groundwater flow also converges locally in heavily pumped areas, including the village of Foremost and the Starbrite Colony (15 km south of Foremost, Alberta). The pressure-depth graphs from Berkenpas (1991) indicate the presence of a region with very low groundwater flow (hydrostatic conditions) southeast of Lake Pakowki (along isoline $910 \mathrm{~m}$ on Fig. 7).

The MRA is a confined aquifer radially dipping from the outcrop areas which presents flowing artesian conditions in some places. Nearly all the wells in southern Alberta were flowing in the pre-exploitation system (Borneuf 1976; Phillips et al. 1986; Hendry et al. 1991). Currently, flowing artesian areas are located in the northern part of the study area and near Lake Pakowki. These locations are still consistent with the flowing artesian limit first observed by Dowling (1917). Depression of the potentiometric surface in the vicinity of the Etzikom or Chin Coulees are attributed to a number of free-flowing wells that lowered the static water levels (Meyboom 1960; Tokarsky 1974). Recently, four new pressure 


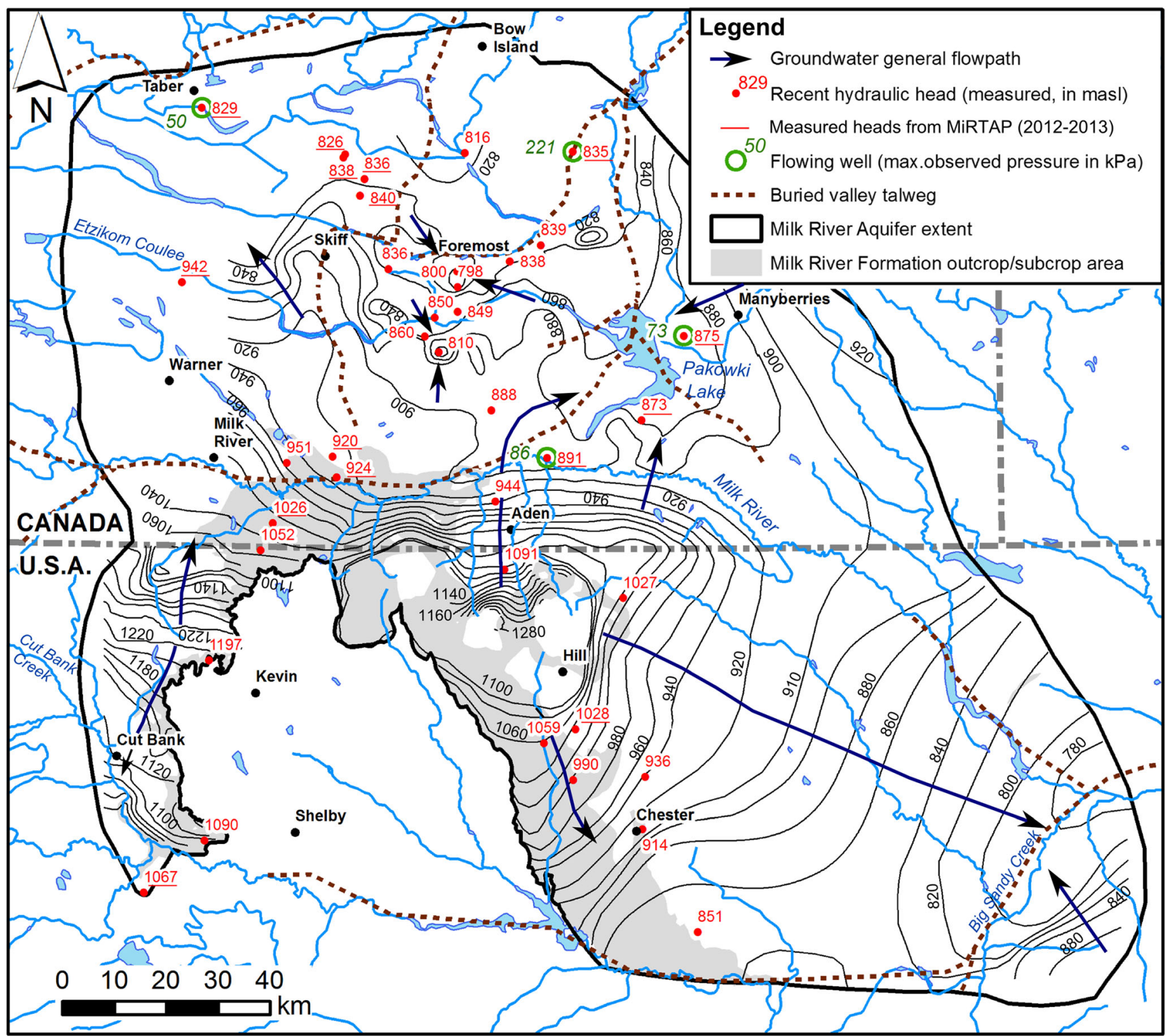

Fig. 7 Transboundary potentiometric surface map of the MRA. Contour intervals are $20 \mathrm{~m}$

measurements were obtained on flowing artesian wells in Alberta in 2013 (Fig. 7). These pressures range from 50 to $221 \mathrm{kPa}(5-22 \mathrm{~m}$ of water) and provide an indication of present-day artesian conditions that still prevail in the MRA.

Although the transboundary potentiometric map of the aquifer is based on four maps representative of various dates and scales, 40 recent data points are consistent with the previous contours maps (except in the areas of heavy pumping where an update of the contours was required). Besides, the hydraulic heads derived from the regional pressure gradients in the northern and eastern limit of the aquifer in Alberta (Berkenpas 1991) are also consistent with the observed hydraulic heads. The potentiometric map is consequently considered as representative at the regional scale.

\section{Transboundary groundwater fluxes}

Groundwater flow diverges from the Sweet Grass Hills to the north, east and southeast, whereas west of the Sweet Grass Arch, groundwater flows south-west and north from a groundwater divide located north of Cut Bank (Fig. 7). Based on these observations, two updated transboundary groundwater flow paths were defined: (1) an eastern flow path from the Sweet Grass Hills to the north and (2) a western flow path from the northern part of Cut Bank to the north.

Estimates of transboundary groundwater fluxes were made using the potentiometric and $T$ maps in Darcybased calculation. The fluxes ( $Q_{\text {east }}$ and $Q_{\text {west }}$ for the eastern and western fluxes, respectively) were calculated using Darcy's law expressed as: $Q=T_{\text {mean }} \times i_{\text {mean }} \times L$ 
where $Q$ is groundwater flow $\left(\mathrm{m}^{3} / \mathrm{y}\right), T_{\text {mean }}$ is the arithmetic mean transmissivity near the international border $\left(\mathrm{m}^{2} / \mathrm{s}\right), i_{\text {mean }}$ is the mean horizontal hydraulic gradient $(\mathrm{m} / \mathrm{m})$, and $L$ is the length of cross-sectional area through which groundwater flows $(\mathrm{m})$.

The value of the total flux $\left(9.0 \times 10^{6} \mathrm{~m}^{3} / \mathrm{y}\right)$ in Table 1 should be considered as a maximum. The total flux is probably overestimated because the high transmissivity values in northern Montana correspond to the most productive areas characterized by fault and fractures.

\section{Recharge areas}

Recharge to the MRA is dominated by infiltration of precipitation in the outcrop and subcrop areas. As most of the study area is covered by glacial drift, recharge waters first enter the unsaturated tills before reaching the Virgelle Member. Robertson (1988) observed that where the low-permeability Deadhorse Coulee Member overlies the Virgelle Member, recharge to the MRA lags and a perched water table can be present.

Limited quantitative information exists concerning the recharge rate of the MRA. An estimate of the effective recharge rate was obtained by assuming the groundwater flux observed at the international border (about $9.0 \times 10^{6} \mathrm{~m}^{3} / \mathrm{y}$ ) is solely due to the portion of potential recharge that actually reaches the aquifer. By dividing this total flux by the area of the MRA outcrop/subcrop that contributes to the transboundary flux $\left(9.28 \times 10^{8} \mathrm{~m}^{2}\right)$, an effective recharge rate of $9.6 \mathrm{~mm} / \mathrm{y}$ was calculated. This value is lower than the potential recharge of about $50 \mathrm{~mm} / \mathrm{y}$ obtained by using the soil-moisture-balance method (Rushton et al. 2006).

Knowing the mean annual precipitation in the outcrop/ subcrop area near the border is about $400 \mathrm{~mm} / \mathrm{y}$ (Climate Canada 2015), the effective recharge represents only $2.4 \%$ of total precipitation. In the prairies of North America, recharge rates range between 2 and $9 \%$ of annual precipitation (Rehm et al. 1982). Using a numerical model, Robertson (1988) obtained smaller values of recharge at the local scale in the subcrop area of $<1 \%$ of total annual precipitation, which were explained by the strong evapotranspiration caused by Chinook (warm dry strong winds). The percentage obtained in the current

Table 1 Estimates of the two transboundary groundwater fluxes across the international border from Montana to Alberta

\begin{tabular}{llllll}
\hline & $T_{\text {mean }}\left(\mathrm{m}^{2} / \mathrm{s}\right)$ & $i_{\text {mean }}(\mathrm{m} / \mathrm{m})$ & $L(\mathrm{~m})$ & $Q\left(\mathrm{~m}^{3} / \mathrm{s}\right)$ & $Q\left(\mathrm{~m}^{3} / \mathrm{y}\right)$ \\
\hline Eastern flux & $1.4 \times 10^{-4}$ & $1.13 \times 10^{-2}$ & 78,500 & 0.12 & $3.9 \times 10^{6}$ \\
Western flux & $5.3 \times 10^{-4}$ & $7.3 \times 10^{-3}$ & 41,500 & 0.16 & $5.1 \times 10^{6}$ \\
Total & - & - & 120,000 & 0.28 & $9.0 \times 10^{6}$ \\
\hline
\end{tabular}

study is thus close to that of Robertson (1988) and in the lower range of Rehm et al. (1982)

Groundwater inflow in the MRA also occurs through subsurface vertical inflow from other geological units in the topographic highs of the study area, as shown in the potentiometric map. As the aquifer is deep $(>400 \mathrm{~m})$ in these areas, this type of inflow would occur at a large time scale and would be less immediate than recharge from precipitation. The flow rates related to these inflows are difficult to estimate and could be better quantified with the use of a numerical model.

\section{Discharge areas}

In southern Alberta, the natural discharge of the MRA has been identified to occur in springs and seeps located on the southern bank of the Milk River and its tributaries (e.g., Verdigris Coulee, Red Creek) whereas in northern Montana discharge occurs in the Sweet Grass Hills area, along Cut Bank Creek and the Virgelle escarpment (Tuck 1993; Meyboom 1960; Zimmerman 1967; Milk River Watershed Council Canada 2008). Indeed, as shown in Fig. 7, the slope of the potentiometric surface is steeper on the southern side when compared to the northern side of the Milk River. This strongly suggests that the Milk River intercepts a substantial volume of the northerly flowing groundwater in the MRA. To assess the magnitude of this water loss, the mean groundwater flux down-gradient from the Milk River was estimated to about $0.4 \times 10^{6} \mathrm{~m}^{3} / \mathrm{y}$ (using the same calculation used to estimate the transboundary flux) with a mean $T$ of $5.1 \times 10^{-5} \mathrm{~m}^{2} / \mathrm{s}$ and a mean hydraulic gradient of $0.2 \%$. Comparing this flux value to the mean groundwater flux up-gradient of the Milk River $\left(9.0 \times 10^{6} \mathrm{~m}^{3} / \mathrm{y}\right)$ suggests that $96 \%$ of the incoming groundwater flux is intercepted by the Milk River and its tributaries after it crosses the international border. The intercepting role of the Milk River is consistent with Berkenpas (1991). In the south-eastern part of the study area near the border (region A or "no-flow area", see Berkenpas 1991), the estimate of the elevation of the water yields a similar elevation as that of the Milk River. This suggests that the greater heads up-gradient of the Milk River are not transmitted beyond the river and that the river intercepts the groundwater flow. In Montana, the natural discharge from springs and seeps in the Sweet Grass Hills area was previously estimated at about $0.6 \times 10^{6} \mathrm{~m}^{3} / \mathrm{y}$ (Tuck 1993). These springs are probably rejected recharge which occurs along the island mountain ranges throughout Montana and are not considered part of the regional groundwater flow system. Rejected recharge occurs at the toe of the mountain recharge areas as a result of dramatically reduced transmissivity of the aquifer away from recharge areas (Huntoon 1985). 


\section{Cross-formational flow}

As no other natural surface outlets have been identified, vertical leakage (or cross-formational flow) from the aquifer through the overlying and underlying geological units must be considered the dominant cause of natural discharge. To estimate the driving forces in place for crossformational groundwater flow, the vertical hydraulic gradients between the MRA and the overlying and underlying units were calculated and represented spatially in southern Alberta where adequate data were available (Fig. 8). In Montana, cross-formational flow is not considered a major issue near the regional recharge area where infiltration enters the MRA but could be in the south-eastern part of the MRA where there is a lack of data to allow an estimation of the magnitude of this process. Hydraulic heads in the MRA were obtained from AGRA Earth and Environmental (1998), the surficial aquifer heads are from Swanick (1982) and the Bow Island Sandstone heads are from Lies and Letourneau (1995). The average thickness of the Colorado Group between the MRA and the Bow Island Sandstone was assumed to be $400 \mathrm{~m}$ based on data from Swanick (1982) and Phillips et al. (1986), whereas the thickness distribution between the MRA and base of the surficial sediments was obtained from the 3D geological model of Pétré et al. (2015). In these calculations, a negative vertical gradient indicates a potential for upward flow, whereas a positive gradient indicates a potential for downward flow. Plots of calculated vertical gradients are presented in Fig. 8. The vertical hydraulic gradients between surficial sediments and the MRA are negative in the vicinity of the Medicine Hat, Skiff and Whisky buried valleys, which indicates an upward flow component from the MRA towards the surficial sediments (discharge conditions). The upward flow component is also confirmed by the presence of many flowing artesian wells in the areas with more negative vertical gradients (Fig. 8a). In the remaining areas, including the central part of the study area and the topographic highs, the vertical hydraulic gradients are positive, indicating a downward flow component from surficial sediments to the MRA. In the central part of the study area, this downward flow is attributed to depressed water levels in the MRA resulting from high pumping rates for long periods, whereas near the USA border it is related to recharge conditions. As depicted in the schematic diagram of Fig. 8c, the high topographic area of the Cypress Hills is also presumed to be a regional recharge area for surficial sediments whose large hydraulic heads induce downward flow through the aquitard overlying the MRA, thus explaining the high potentiometric heads observed east of Manyberries (Fig. 7). This cross-formational flow process was also inferred by Toth and Corbet (1986).
By comparing the hydraulic heads in the surficial aquifer, the MRA and the Bow Island sandstone on a cross-section, Phillips et al. (1986) concluded that the water leaves the aquifer via vertical leakage. From Fig. 8a, it appears that crossformational flow focused on the buried valley talwegs that have eroded the upper bedrock (Belly River/Judith River and Pakowki/Claggett formations), thus reducing the vertical distance between the MRA and permeable surficial sediments. Besides, the Pakowki/Claggett Aquitard overlying the MRA thins from about $130-100 \mathrm{~m}$ in the west and central parts of the study area to $40-60 \mathrm{~m}$ west of Skiff. This could also facilitate vertical leakage.

Figure 8a supports the interpretation of Toth and Corbet (1986) who state that the topographic highs in the study areas constitute areas of recharge to the MRA. Toth and Corbet (1986) had also drawn a potentiometric map of the MRA that took into account the presence of buried valleys that were inferred to be zones of flow convergence in the MRA due to the preferential cross-formational upward flow from the MRA where buried valleys are located.

The vertical hydraulic gradient between the MRA and the Bow Island sandstone is positive in southern Alberta (Fig. 8b). This indicates a downward flow component from the aquifer to the Colorado Group throughout southern Alberta; however, the vertical gradient is very small, approximately zero in the Foremost area and is attributed to a depression in the hydraulic head from extensive historical pumping. This downward flow is consistent with the suggestion from Toth and Corbet (1986) and Hendry and Schwartz (1988) that the Colorado Group is a potential sink for water from the MRA. This mechanism could result from the elastic rebound of the shales in the Colorado Group after the 700-m erosion of the land surface during the Pliocene and Pleistocene (Toth and Corbet 1986). Figure 8c summarizes the implications of the mapped vertical hydraulic gradients on cross-formational flow to and from the MRA using a schematic cross-section of the aquifer system.

The same calculations were not applied in Montana due to a lack of data; however, east of the Sweet Grass Arch, in the vicinity of Big Sandy Creek, the heads in the Judith River Formation (equivalent of Belly River Formation; Levings 1982b) are lower than those in the Milk River Formation (Eagle Formation; Levings 1982a). These data indicate an upward cross-formational flow component from the aquifer to the surficial sediments in this area. Although the fluxes related to this upward flow could not be quantified, they are inferred to be small because the MRA is deep in this part of the system.

\section{Hydrogeochemical conditions}

The groundwater geochemistry of the MRA provides key indications that can be used for the development of the aquifer 
a

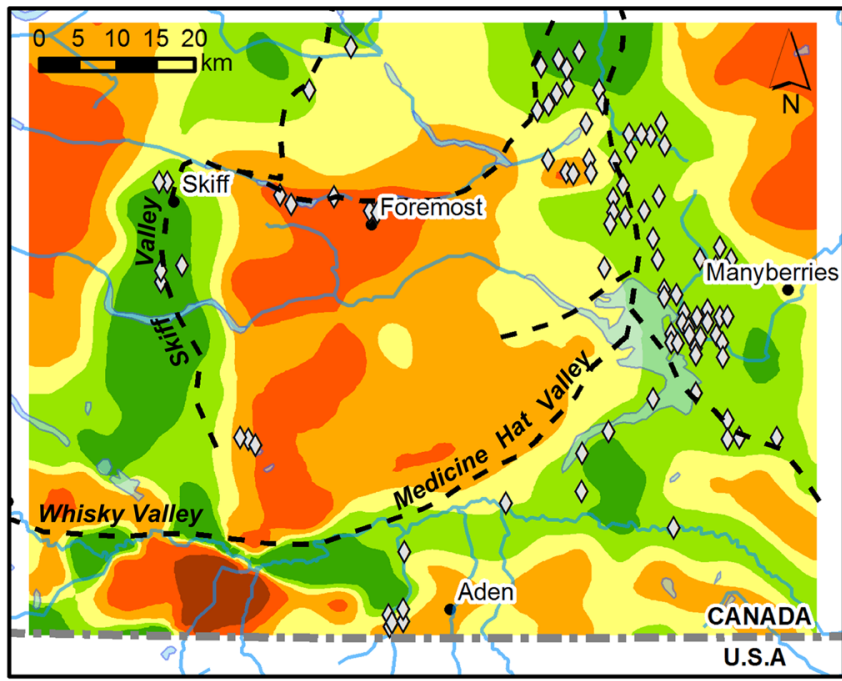

\section{C}

West b

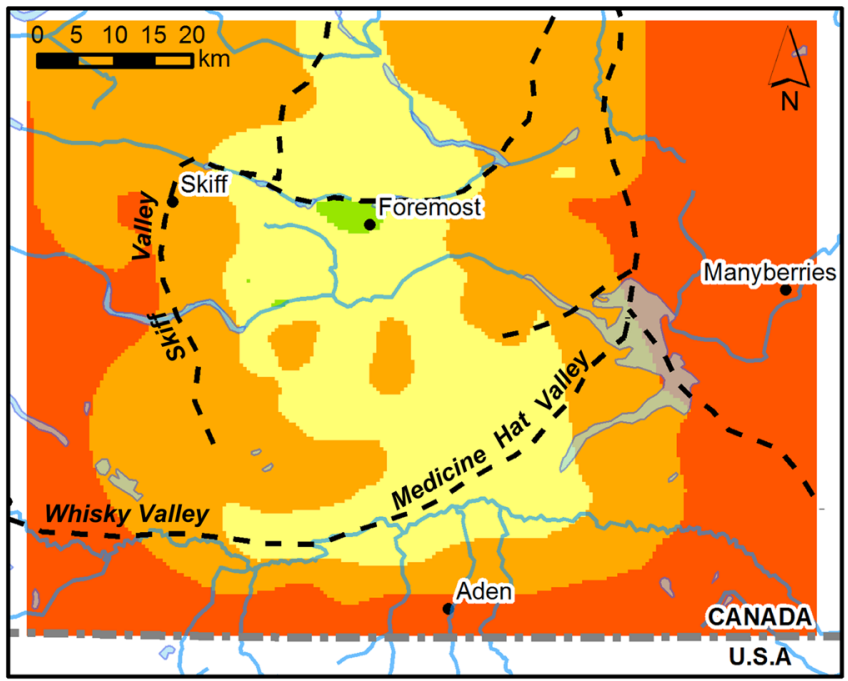

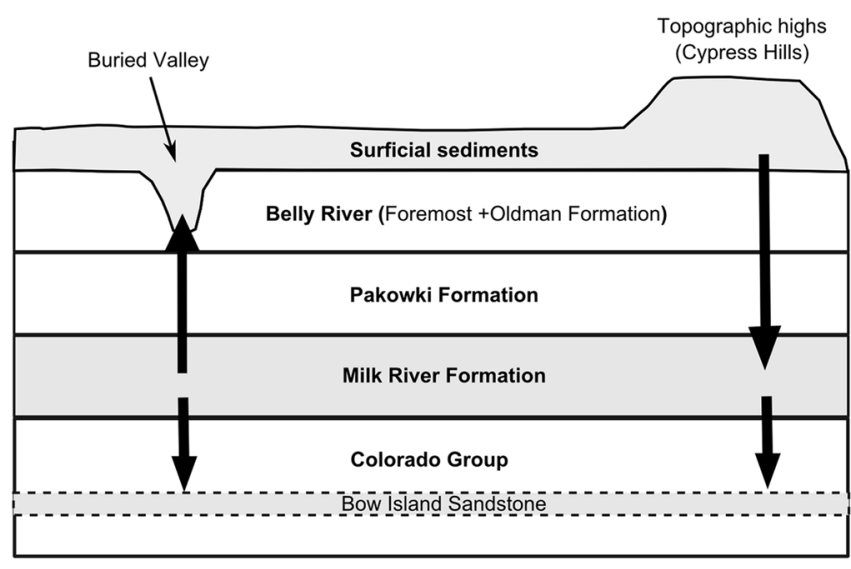

Advective flux

\section{Legend}

- Bedrock valley talweg

$\diamond \quad$ Flowing well (AGRA 1998)

Vertical hydraulic gradient
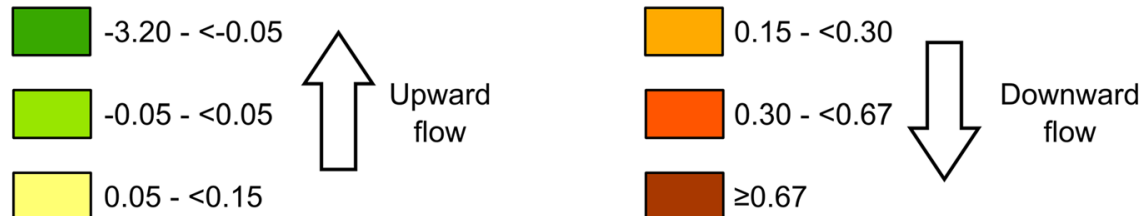

Fig. 8 Vertical hydraulic gradients in southern Alberta between a overlying surficial sediments and the MRA and $\mathbf{b}$ the MRA and the underlying Bow Island Sandstone. Negatives values reflect upward flow. c Vertical flow tendencies schematically represented in the diagram (not to scale)

system conceptual model. Geochemical patterns of chemical components and isotopes provide indications on how the aquifer system functions and the geochemical and flow processes that may take place.

\section{Water types and major ions}

Groundwater chemical analyses for the MRA were obtained from various sources in Alberta and Montana, 


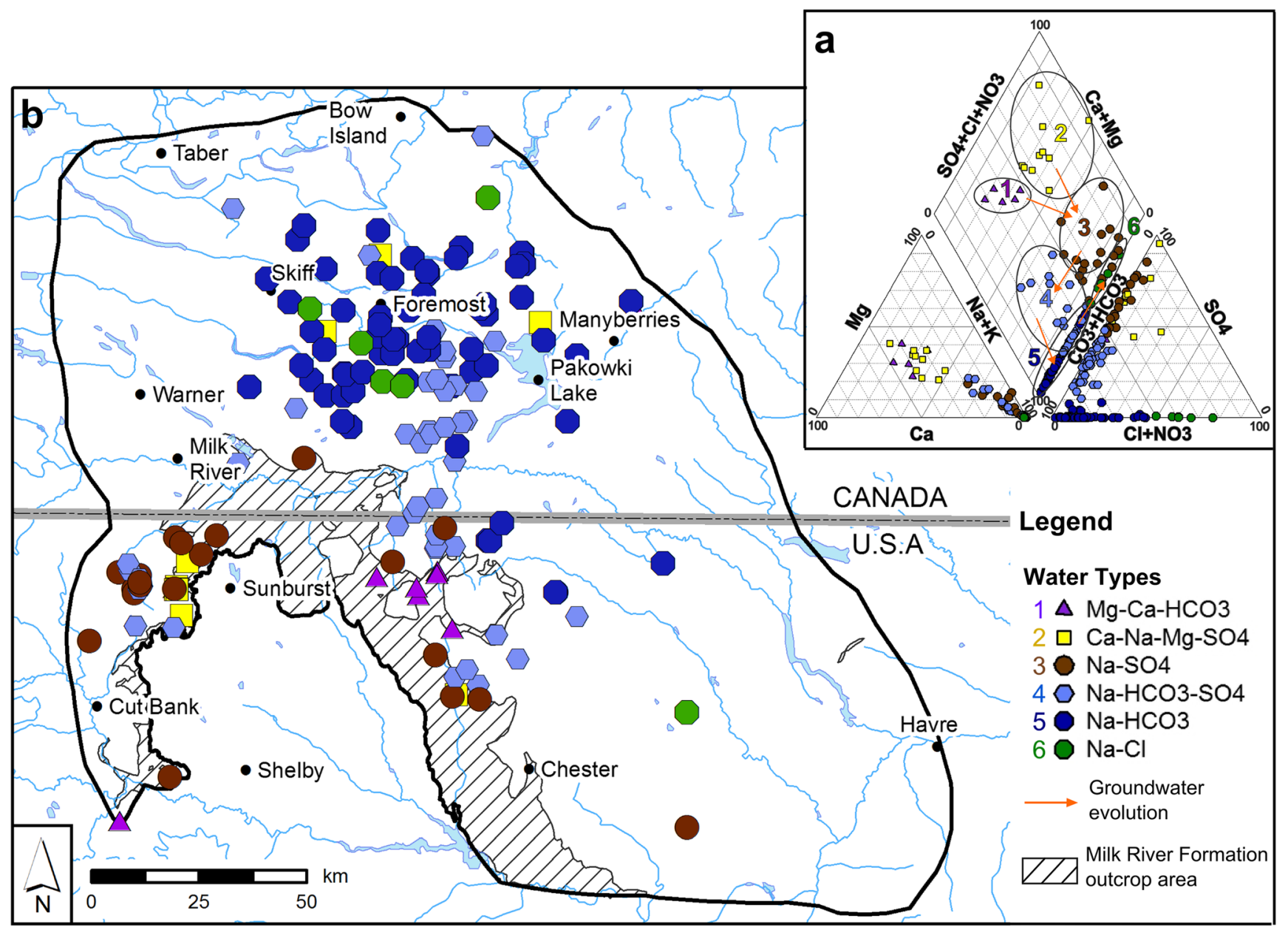

Fig. 9 a Piper diagram showing the six water types identified in the MRA b Spatial distribution of groundwater types in the study area

including Wozniak et al. (2011); GWIC (2015); Tuck (1993); PFRA (unpublished report, 2006) and Milk River Watershed Council Canada (2011). In addition, chemical analyses of samples from the MiRTAP fieldwork in Montana (in 2013) were included. Only water analyses with a charge balance error less than $\pm 10 \%$ were used. This resulted in a dataset of 151 samples. Major cations and anions were used to determine the groundwater type. The proportions of major ions are presented on a Piper diagram (Piper 1944; Fig. 9a). Six water types were defined, and their spatial distribution presented in Fig. 9b
Table 2 presents the location of water types in the MRA from the compiled water sampling dataset. Group 1 water also included some sulfates occurring as a minor ion. Sulfate-dominant type $\left(\mathrm{Na}-\mathrm{SO}_{4}, \mathrm{Mg}-\mathrm{SO}_{4}\right.$ and $\mathrm{Ca}-$ $\mathrm{SO}_{4}$ ) are located mostly in northern Montana and southern Alberta, in the vicinity of the subcrop areas of the Milk River Formation. Sodium-chloride type is found in the less transmissive parts of the study area. In the southeastern corner of the study area, recent data are scarce but Swenson (1957) indicates that sodium-chloride $(\mathrm{Na}-\mathrm{Cl})$ type is prevalent.
Table 2 Location of water types in the MRA

\begin{tabular}{lll}
\hline Group No. & Water type & Location of positive samples \\
\hline 1 & $\mathrm{Ca}-\mathrm{Mg}-\mathrm{HCO}_{3}$ & Sweet Grass Hills \\
2 & Mixed cations-SO & Outcrop area (Montana) and central part of the study area \\
3 & $\mathrm{Na}-\mathrm{SO}_{4}$ & Outcrop area \\
4 & $\mathrm{Na}-\mathrm{HCO}_{3}-\mathrm{SO}_{4}$ & Downgradient of the outcrop area \\
5 & $\mathrm{Na}-\mathrm{HCO}_{3}$ & Prevalent in Alberta and along the international border in Montana \\
6 & $\mathrm{Na}-\mathrm{Cl}$ & Less transmissive parts of the study area \\
\hline
\end{tabular}


Table 3 Proposed processes explaining the geochemical patterns in the MRA

\begin{tabular}{|c|c|c|}
\hline Geochemical evolution & Proposed process & References \\
\hline Presence of $\mathrm{SO}_{4}{ }^{2-}$ in outcrop area & Percolation of freshwater through the glacial till & $\begin{array}{l}\text { Swanick(1982), Robertson (1988), Hendry } \\
\text { and Schwartz (1990) }\end{array}$ \\
\hline \multirow[t]{2}{*}{ Decrease in $\mathrm{SO}_{4}^{2-}$ down-gradient } & Sulfate reduction & $\begin{array}{l}\text { Schwartz and Muelhenbachs (1979), } \\
\text { Swanick (1982), Phillips et al. (1986), } \\
\text { Drimmie et al. (1991) }\end{array}$ \\
\hline & Geological control & Hendry and Schwartz (1990) \\
\hline \multirow[t]{2}{*}{$\begin{array}{l}\text { Increase in } \mathrm{Na}^{+} \text {and decrease in } \\
\mathrm{Ca}^{2+} \text { and } \mathrm{Mg}^{2+} \text { down-gradient }\end{array}$} & Ion exchange & $\begin{array}{l}\text { Schwartz and Muehlenbachs 1979, } \\
\text { Swanick (1982), Phillips et al. (1986), } \\
\text { Robertson (1988) }\end{array}$ \\
\hline & Diffusion of $\mathrm{Na}$ from the confining shales & Hendry and Schwartz (1990) \\
\hline \multirow[t]{2}{*}{ Increase in $\mathrm{HCO}_{3}{ }^{-}$down-gradient } & Calcite dissolution & Meyboom (1960), Swanick (1982) \\
\hline & Production of $\mathrm{CO}_{2}$ during methanogenesis & Phillips et al. (1986) \\
\hline \multirow[t]{5}{*}{$\mathrm{Cl}^{-}$spatial distribution } & $\begin{array}{l}\text { Megascopic dispersion with upward leakage } \\
\text { of connate water }\end{array}$ & Schwartz and Muehlenbachs (1979) \\
\hline & $\begin{array}{l}\text { Limited recharge area (displacement of connate } \\
\text { water by large scale mixing with recharge water) }\end{array}$ & Domenico and Robbins (1985) \\
\hline & Membrane filtration & Phillips et al. (1986) \\
\hline & $\begin{array}{l}\text { Aquitard diffusion (diffusion of } \mathrm{Cl}^{-} \text {into the aquifer } \\
\text { from shale confining units) }\end{array}$ & Hendry and Schwartz (1988) \\
\hline & $\begin{array}{l}\text { Internal saline source (diffusion of saline water from } \\
\text { the less-permeable members of the Milk River Formation) }\end{array}$ & Fabryka-Martin et al. (1991) \\
\hline
\end{tabular}

Based on the general flowpaths defined in Fig. 7, the inferred evolution of the MRA waters is essentially from groups 1 and 2 to groups 3, 4, 5 and 6. Several processes have been proposed to explain the observed changes in water composition as the water flows down-gradient (Table 3).

The spatial distribution of individual major ions $\left(\mathrm{Na}^{+}\right.$, $\mathrm{Mg}^{2+}, \mathrm{Ca}^{2+}, \mathrm{Cl}^{-}, \mathrm{HCO}_{3}{ }^{-}, \mathrm{SO}_{4}{ }^{2-}$ ) in southern Alberta was described by Schwartz and Muehlenbachs (1979); Schwartz et al. (1981) and Hendry and Schwartz (1990). Transboundary maps for these ions are presented by Rivera et al. (Geological Survey of Canada, Quebec, Canada, unpublished report, 2016). With the exception of sulfate, the concentration of major ions increases progressively along the flowpaths from the recharge area. In this study, the chloride $\left(\mathrm{Cl}^{-}\right)$concentrations are described in detail, as chloride is considered as a conservative tracer in the aquifer system.

Figure 10 shows the spatial distribution of $\mathrm{Cl}^{-}$concentrations in the MRA. $\mathrm{Cl}^{-}$concentrations increase from the recharge area to the north in Alberta and to the south-east and south-west in Montana. This increase follows the general groundwater flow paths. However, the $\mathrm{Cl}^{-}$concentration pattern in southern Alberta is complex. Indeed, two protrusions of more dilute waters are present in southern Alberta (Fig. 10). The area of dilute water can be extended to the east in southern Alberta, near Lake Pakowki. These areas correspond to the most transmissive parts of the MRA (Fig. 6). This pattern is also shown in southern Alberta in the spatial distribution of other halogens and stable isotopes $\left(\delta^{18} \mathrm{O}\right.$ and $\delta^{2} \mathrm{H}$; Hendry and Schwartz
1990; Fabryka-Martin et al. 1991). These data are not available for Montana.

Hendry and Schwartz (1988) used the $\mathrm{Cl}^{-}$distribution in the MRA to determine the main groundwater flowpaths, assuming that the groundwater flow followed areas from low to higher $\mathrm{Cl}^{-}$concentration. They considered that hydraulic heads were not appropriate for the delineation of the groundwater flow paths that have dominated over geological time as they represent modern conditions influenced by pumping activities (Fröhlich et al. 1991). Thus, eastern and western flowpaths were delineated, following the two protrusions of low $\mathrm{Cl}^{-}$, on both sides of the low- $T$ area (Fig. 10). Moreover, the transboundary map of $\mathrm{Cl}^{-}$also shows that a flowpath directed towards Lake Pakowki should exist as well as another flowpath to the southeast in Montana. Preferential flowpaths inferred from low $\mathrm{Cl}^{-}$concentrations are coherent with indications provided by the potentiometric map and also correspond to zones of higher transmissivity (Fig. 6). The configuration of $\mathrm{Cl}^{-}$concentration in southern Alberta suggests that the dilute recharge waters displace connate waters along the most transmissive portions of the aquifer, instead of following a uniform recharge front (Fabryka-Martin et al. 1991). Evidence of this may be the high $\mathrm{Cl}^{-}$waters found south of Foremost and east of Chester in Montana, which are less permeable zones (Figs. 10 and 6a).

Five processes have been proposed to explain the chloride concentration pattern observed in the MRA (Table 3): (1) megascopic dispersion with upward leakage of connate water (Schwartz and Muehlenbachs 1979); (2) displacement of 


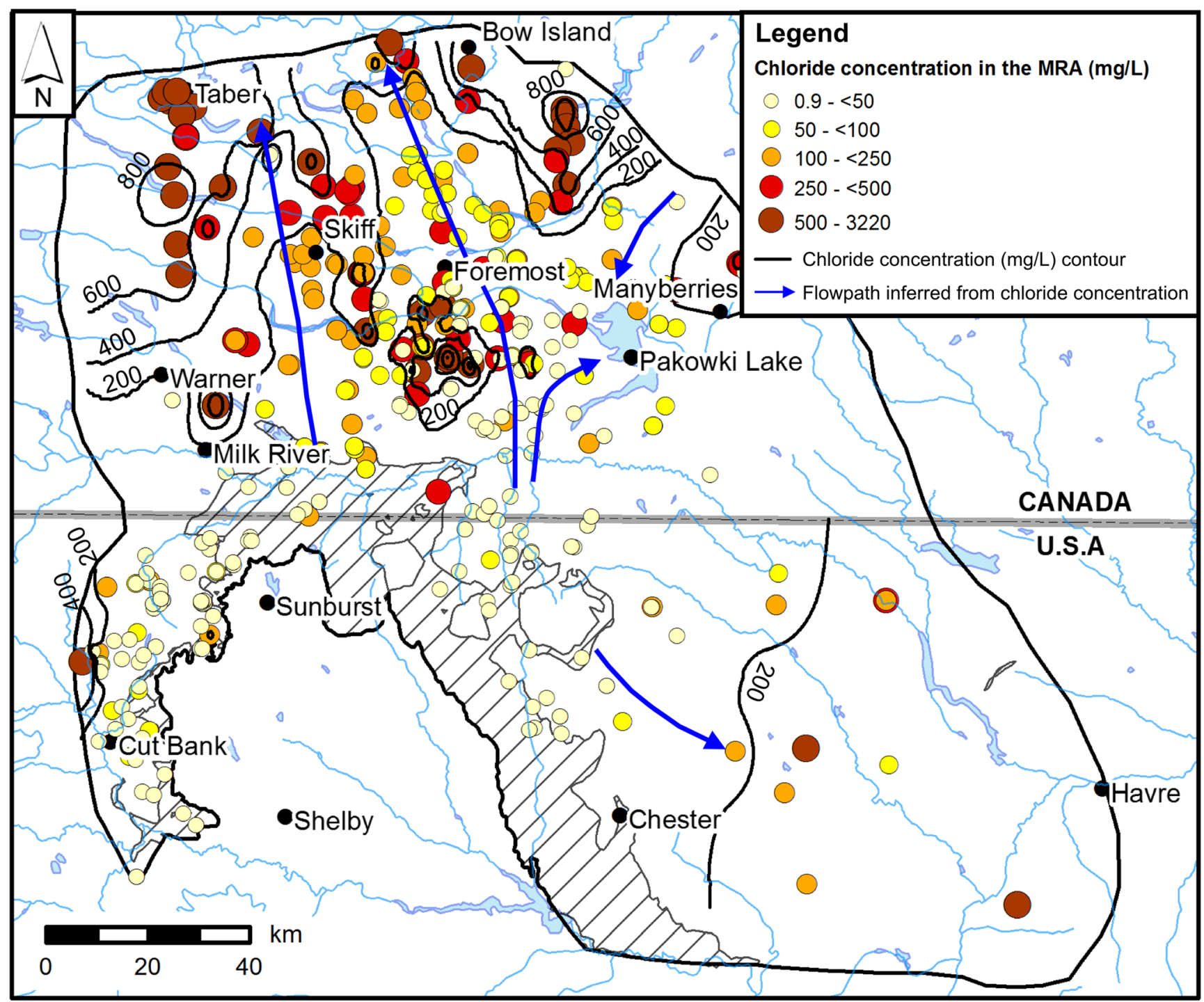

Fig. $10 \mathrm{Cl}^{-}$concentrations in the MRA. Contour interval is $200 \mathrm{mg} / \mathrm{L}$. Preferential flowpaths indicated by blue arrows are inferred from low $\mathrm{Cl}^{-}$ concentrations

connate water by large-scale mixing with recharge water (Domenico and Robbins 1985); (3) membrane filtration (Phillips et al. 1986); (4) diffusion of $\mathrm{Cl}^{-}$into the aquifer from shale confining units (Hendry and Schwartz 1988) and (5) diffusion of saline water from the less-permeable members of the Milk River Formation (internal saline source; Fabryka-Martin et al. 1991). Beside diffusion from an internal saline source, Fabryka-Martin et al. (1991) indicate that the first four mechanisms "cannot be ruled out altogether and are probably contributing to the groundwater geochemistry to some extent".

The geochemical transboundary maps (Figs. 9b and 10) suggest that the evolution of water types in the MRA is similar in Alberta and Montana, although more evolved water types are present in Alberta. It can then be assumed that the geochemical water types in the MRA are continuous across the international border and that some of the proposed processes in southern Alberta (Table 3) might also be active in Montana. However, a full geochemical study including a complete dataset on both sides of the border would be necessary in order to determine which of the previously cited processes are truly controlling groundwater geochemistry.

\section{Stable and radiogenic isotopes}

To provide a unified portrait of the aquifer, recent isotopic analyses $\left({ }^{3} \mathrm{H},{ }^{14} \mathrm{C},{ }^{13} \mathrm{C}\right.$ and $\left.{ }^{36} \mathrm{Cl}\right)$ of samples from the MiRTAP fieldwork were added to the historical dataset.

Radioactive isotopes such as ${ }^{3} \mathrm{H},{ }^{14} \mathrm{C}$ and ${ }^{36} \mathrm{Cl}$ are commonly used for groundwater dating (Kazemi et al. 2006). In the perspective of an effective management of groundwater resources, groundwater residence time is an important parameter, as old waters within an aquifer system generally indicate that the resource may not be being renewed. 
a

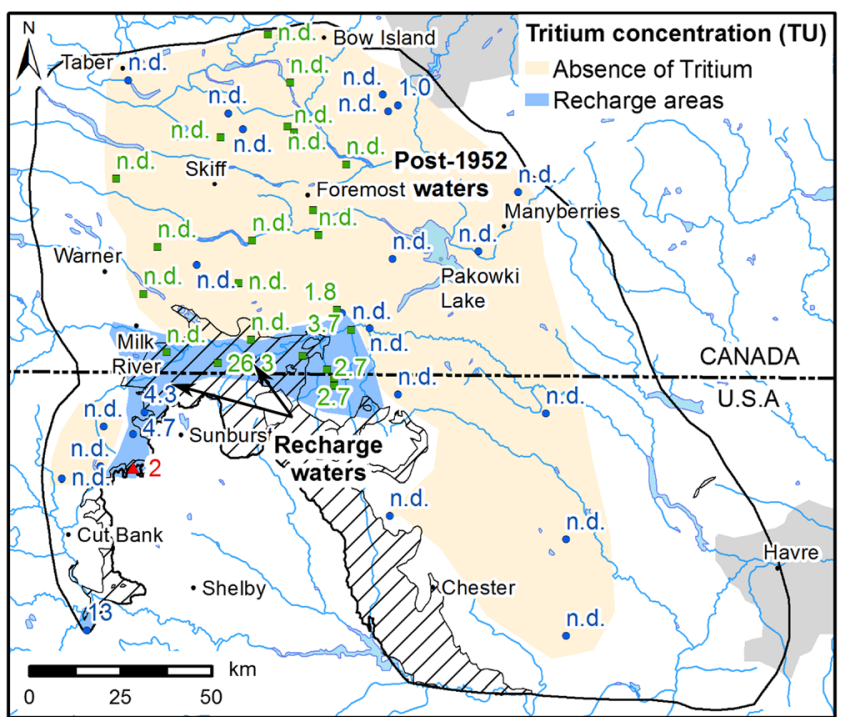

C

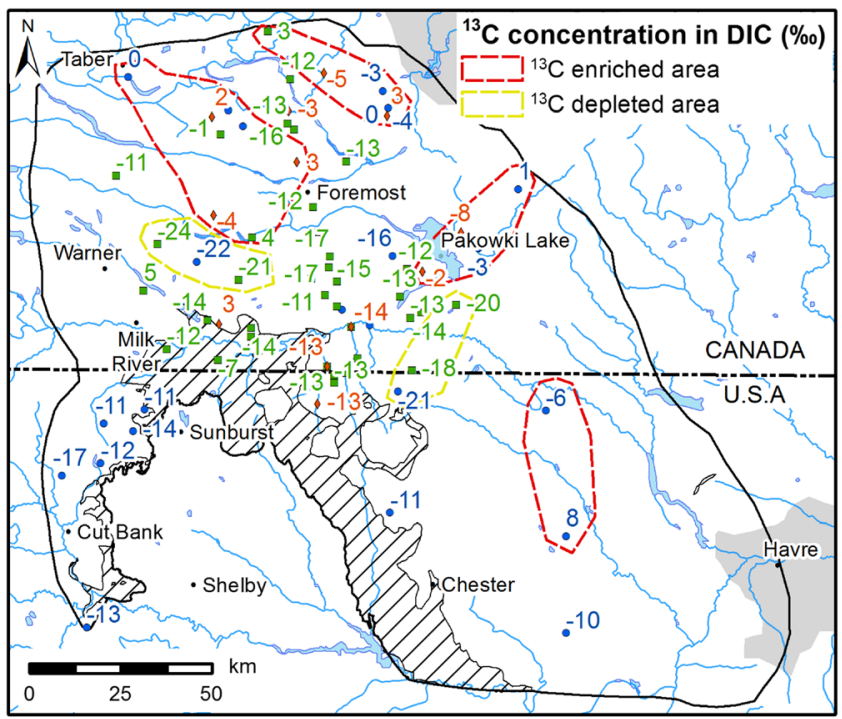

Legend

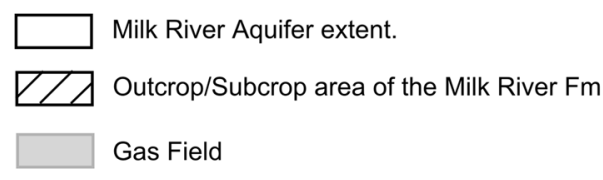

"n.d" stands for "non-detected"

Fig. 11 Isotopic maps of the MRA; ${ }^{3} \mathrm{H}$ concentration (in tritium units, TU) $\mathbf{b}{ }^{14} \mathrm{C}$ concentration in dissolved inorganic carbon (DIC, in percent modern carbon) $\mathbf{c} \delta^{13} \mathrm{C}$ concentration in dissolved inorganic carbon (\%o)

In 1984, an International Atomic Energy Agency (IAEA) sponsored study was conducted on the MRA in Alberta to test methods for dating old groundwaters. A series of papers resulted from this study (Ivanovich et al. 1991) and a comprehensive review of these studies has been proposed by Fröhlich et al. (1991) and Fröhlich (2013). The MRA has been

\section{b}

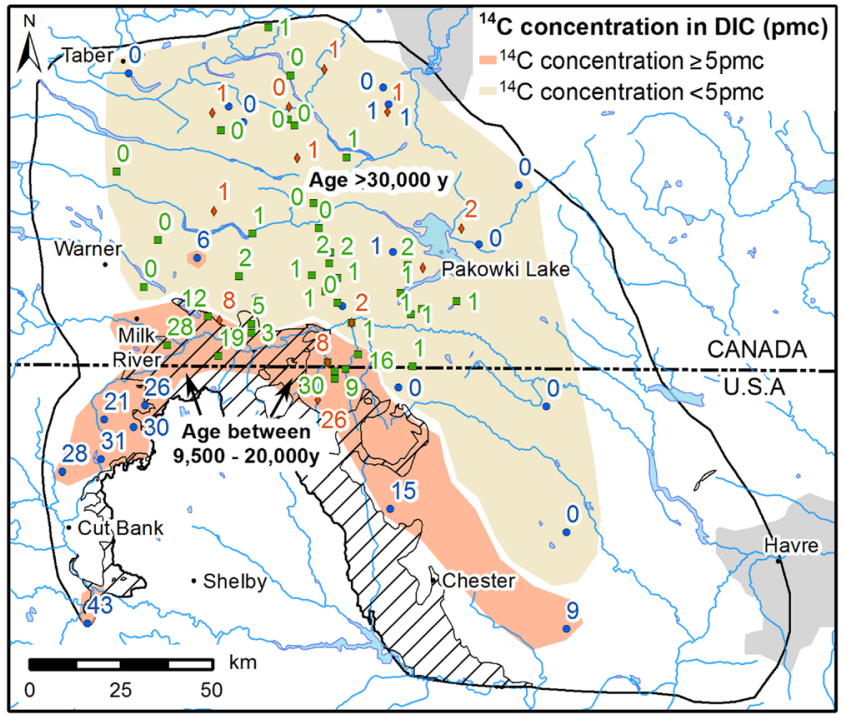

d

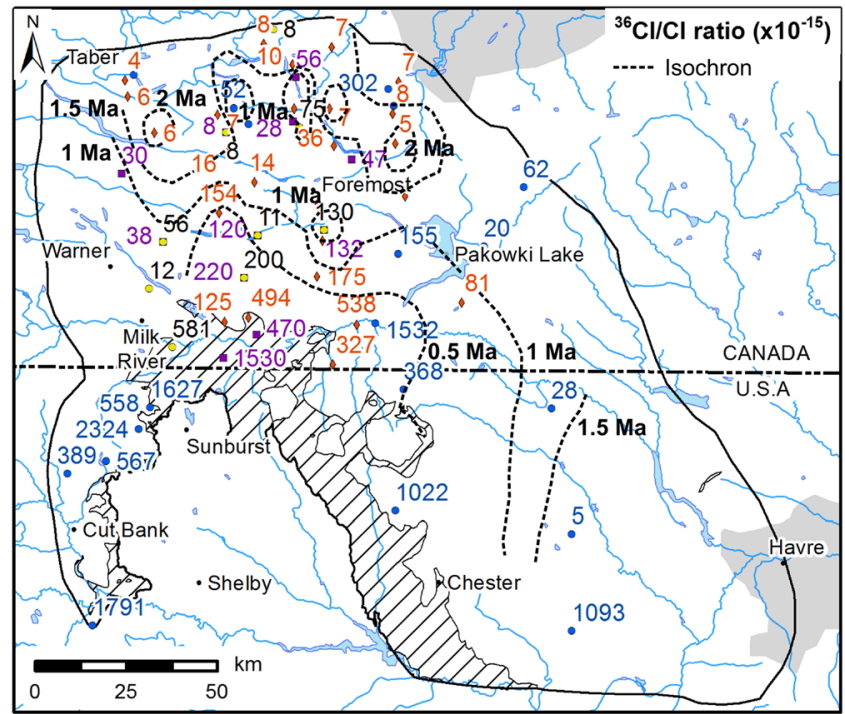

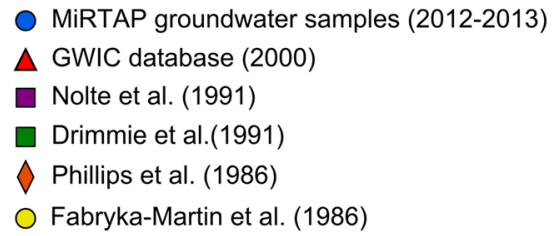

d ${ }^{36} \mathrm{Cl} / \mathrm{Cl}$ ratio $\left(\mathrm{x} 10^{-15}\right)$ and mean age calculated from Eq. (1) (see Appendix; Bentley et al. 1986)

described as complex both in terms of groundwater origin and the evolution of its chemical and isotopic contents (Fröhlich et al. 1991).

Available isotopic data for ${ }^{3} \mathrm{H},{ }^{14} \mathrm{C},{ }^{13} \mathrm{C}$ and ${ }^{36} \mathrm{Cl}$ are shown on maps in Fig. 11. The recent MiRTAP data are mostly collected to fill in data gaps, especially in Montana and east of 
Lake Pakowki in Alberta. Figure 11a illustrates the tritium values from three sources: the recent MiRTAP fieldwork, the GWIC database (only one analysis available in 2000) and Drimmie et al. (1991). A qualitative interpretation of tritium data can be made as detectable concentrations of tritium (halflife of 12.3 years) indicate a component of modern recharge (Clark and Fritz 1997). In most sampling sites, tritium concentrations are below the detection limit $(0.8 \mathrm{TU})$, which indicates post-1952 waters. Detectable tritium concentrations were measured in the outcrop areas of the Milk River Formation both in southern Alberta and northern Montana. The absence of tritium in the central part of the study area is consistent with Lehman et al. (1991) who tested ${ }^{85} \mathrm{Kr}$ (half-life of 10.6 years) on a water well located $20 \mathrm{~km}$ north of the Milk River, and observed that no young water component was present.

The ${ }^{14} \mathrm{C}$ (half-life of 5,730 years) data are presented in Fig. 11b. They are reported in dissolved inorganic carbon (DIC) as percent modern carbon (pmc) as defined by Stuiver and Polach (1977). Recent data collected through the MiRTAP project are consistent with the historical data. Most locations in Alberta have ${ }^{14} \mathrm{C}$ values ranging from below the detection limit to $2 \mathrm{pmc}$, indicating that the groundwater has very little to no ${ }^{14} \mathrm{C}$; therefore, the residence time of groundwater is greater than 30,000 years in the areas with a low ${ }^{14} \mathrm{C}$ value (Clark and Fritz 1997). Higher ${ }^{14} \mathrm{C}$ values were measured near the US-Canada border, in the outcrop area of the Milk River Formation, in the vicinity of the Sweet Grass Hills, and in the entire south-west corner of the study area. Estimated uncorrected ${ }^{14} \mathrm{C}$ groundwater age in this area varies from 9,500 to 20,000 years. This range is consistent with Wassenaar et al. (1991) who obtained ${ }^{14} \mathrm{C}$ ages of 6,300 and 22,600 $y$ for two wells south of the Milk River from dissolved organic carbon.

Figure $11 \mathrm{c}$ illustrates the spatial distribution of $\delta^{13} \mathrm{C}$ values for the MRA as well as the zones where $\delta^{13} \mathrm{C}$ is depleted or enriched. The recent results (MiRTAP samples) are consistent with historical data (Philips et al. 1986; Drimmie et al. 1991). The red polygons indicate locations where $\delta^{13} \mathrm{C}$ values are enriched and yellow ones where $\delta^{13} \mathrm{C}$ values are depleted. In either case, there is no radiocarbon left at those locations. The enriched $\delta^{13} \mathrm{C}$ values in the northern part of the study area may be due to calcite solution and methanogenic $\mathrm{CO}_{2}$ (Phillips et al. 1986; Drimmie et al. 1991; Clark and Fritz 1997). The lowest $\delta^{13} \mathrm{C}$ values indicate methane oxidation or organic carbon reduction (Drimmie et al. 1991; Clark and Fritz 1997).

As there is no ${ }^{14} \mathrm{C}$ signal beyond the Milk River, chlorine -36 (half-life 301,000 years) was chosen as a dating tool for the groundwater in the remaining part of the study area (Phillips et al. 1986; Fabryka-Martin et al. 1991; Nolte et al.
1991). Recent ${ }^{36} \mathrm{Cl}$ data obtained from the current study were added to the historical data. The spatial distribution of the ${ }^{36} \mathrm{Cl} / \mathrm{Cl}$ ratio in the study area shows that the ratios decrease with distance down the flow lines, as $\mathrm{Cl}$ concentration increases (Fig. 11d). In the northern part of the study area and south-east of the Sweet Grass Hills, the ${ }^{36} \mathrm{Cl} / \mathrm{Cl}$ ratio reaches a value of about $4-8 \times 10^{-15}$. This range corresponds to the secular equilibrium value in sandstone (i.e. production rate equals the decay rate; Bentley et al. 1986). The large area with secular equilibrium indicates that the chlorine at the distal end of the MRA is older than 2.5 Ma (Bentley et al. 1986). Isochrons based on ${ }^{36} \mathrm{Cl} / \mathrm{Cl}$ ratios were previously mapped by Phillips et al. (1986) in southern Alberta. To update and extend isochrons into Montana, ages have been calculated using the standard equation from Bentley et al. (1986), as previously done by Phillips et al. (1986; see Appendix). It is noteworthy that different corrections to this standard equation can be used, depending on the process considered (aquitard diffusion, mineral dissolution; Bentley et al. 1986).

Samples with measurable radiocarbon or tritium were rejected as they are too young to be dated by ${ }^{36} \mathrm{Cl}$. The initial ${ }^{36} \mathrm{Cl} / \mathrm{Cl}$ ratio value has been updated from $500 \times 10^{-15}$ (Phillips et al. 1986) to $1,000 \times 10^{-15}$ (Davis et al. 2000). The resulting isochrons range from $0.5 \mathrm{Ma}$ up-gradient to 2 Ma down-gradient (Fig. 11d). This range of values should be considered as a time frame in the regional transboundary transport of solutes within the system. This extended map shows an increase in age eastward along the international border and south-east in Montana. The presence of very old waters in this area is consistent with the hydrodynamics of the MRA and the evolved geochemical water types that are observed.

Water ages derived from isotopic data are generally greater than those obtained from hydraulic data (Bethke and Johnson 2002). Schwartz and Muelhenbachs (1979) present a maximum age of the MRA waters of 300 , 000 years based solely on hydraulic arguments. Swanick (1982) obtained ages up to 500,000 years near Taber from a steady-state quasi three-dimensional (3D) model. Hendry and Schwartz (1988) used a hydrodynamic model to calculate ages of 250,000 and 500,000 years for the eastern and western flowpaths in southern Alberta (Fig. 10), respectively. Several factors explain the difference between the hydrodynamic age and the isotopic age. In a heterogeneous aquifer, the comparison between isotopic age and advective ages may not be relevant since there is a dispersion mechanism occurring within the aquifer. Besides, the glaciations during the Pleistocene may have limited the water movement in the MRA and this effect could be taken into account in the estimation of the water age (Bentley et al. 1986; Fabryka-Martin et al. 1991). Fröhlich et al. (1991) and Fabryka-Martin et al. (1991) suggested that groundwater ages obtained from 
Fig. 12 Delineation of three natural zones (zone $1 a / 1 b$, zone 2 , and zone 3 ) of the MRA and their surface areas

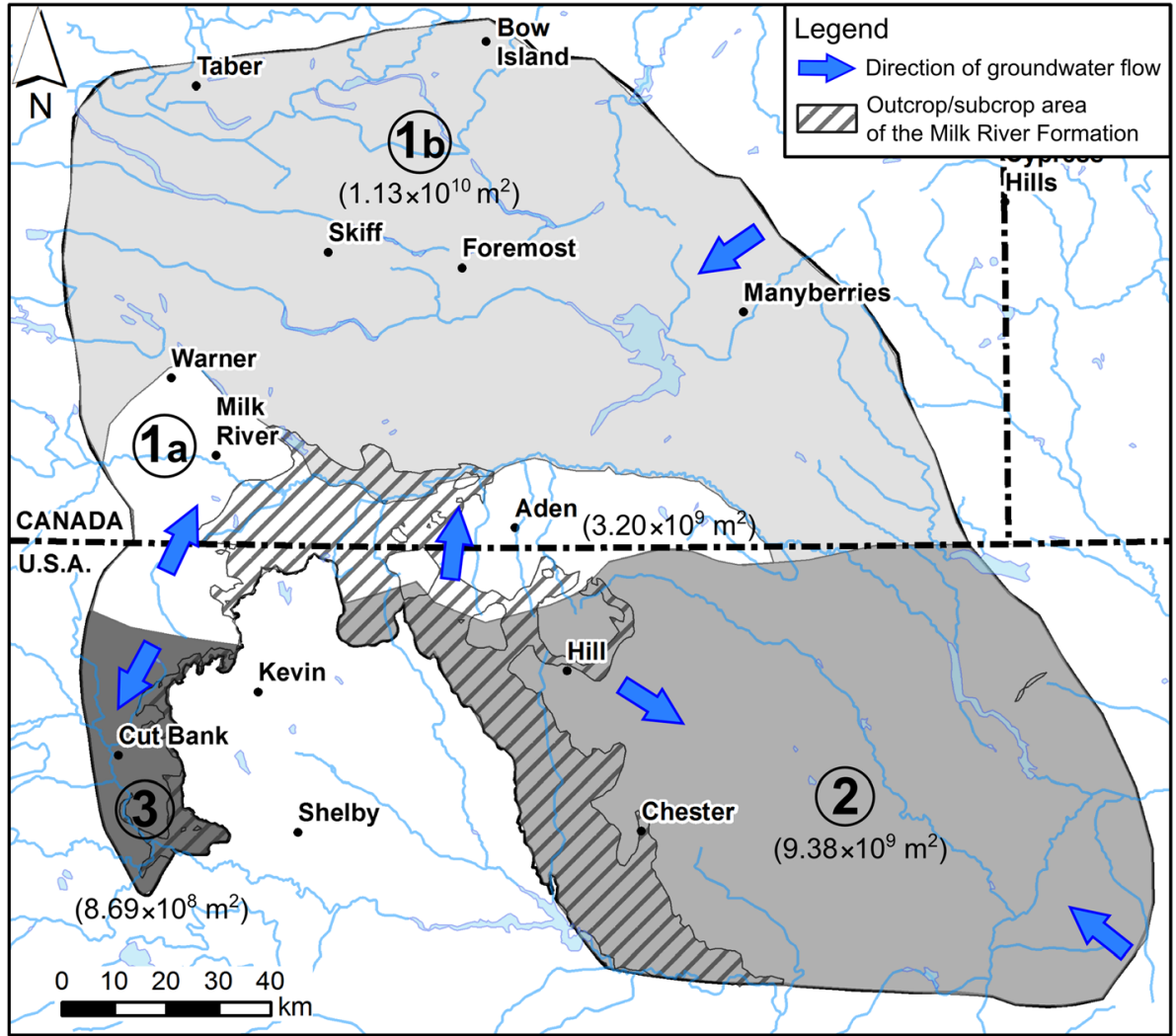

hydrodynamic models should be envisaged as a lower limit of the average groundwater ages while those based on ${ }^{36} \mathrm{Cl}$ data should be envisaged as an upper limit.

\section{Conceptual model}

The hydrogeological and geochemical evidence presented in the previous sections allowed the development of a comprehensive conceptual model of the MRA following its natural boundaries. On the basis of groundwater divides inferred from the potentiometric map (Fig. 7), the MRA can be divided into three natural sub-systems, in which groundwater flows in different directions, and discharges into three distinct locations (Fig. 12). Zones 1, 2 and 3 were delineated. Zone 1 corresponds to the area where groundwater flows from northern Montana to southern Alberta. A distinction is made between the portion located up-gradient (zone 1a) and down-gradient from the Milk River (zonelb), which intercepts a large part of the transboundary flux coming from northern Montana. Zone $1 \mathrm{~b}$ also includes the groundwater flow from the Cypress Hills. Zone 2 comprises the southeastern part of the study area in Montana, in which groundwater flows from the Sweet Grass Hills and Bears Paw Mountains to the Big Sandy Creek area. Zone 3 is located in the south-western part of the study area.
The MRA is under unconfined or semi-confined conditions in the outcrop and subcrop areas of the Virgelle Member as shown on the conceptual hydrogeological cross-section in Fig. 13. The level of confinement of the aquifer is due to changes in surface topography, especially due to the presence of coulee and river valleys and the presence of buried valleys eroding part of the aquitards above the MRA. The MRA presents flowing artesian conditions in the northern part of the study area. The study of the groundwater flow and the quantification of the fluxes up-gradient and down-gradient from the Milk River show the main discharge mechanism of the MRA in southern Alberta was from interception of flow by the Milk River. Several studies established that the Milk River acted as a point of discharge for the MRA rather than recharge (Meyboom 1960; Robertson 1988; Drimmie et al. 1991, Fröhlich 2013); however, previous estimates of the volume of the springs and seeps along the Milk River were about $5.8 \times 10^{-2} \mathrm{~m}^{3} / \mathrm{s}$ (Meyboom 1960) or $9.0 \times 10^{-3} \mathrm{~m}^{3} / \mathrm{s}$ (Robertson 1988). These values are lower than the current estimate of about $0.3 \mathrm{~m}^{3} / \mathrm{s}$ because they were obtained considering that the discharge into the river only takes place along the $30 \mathrm{~km}$ outcrop of Virgelle Member, where it is incised by the Milk River (Fig. 2). The potentiometric map (Fig. 7) as well as the isotopic data (Fig. 11) rather indicate that the groundwater flow is intercepted along the entire length of the Milk River in Alberta and part of the Verdigris Coulee even if the hydraulic connection is indirect. This mechanism 


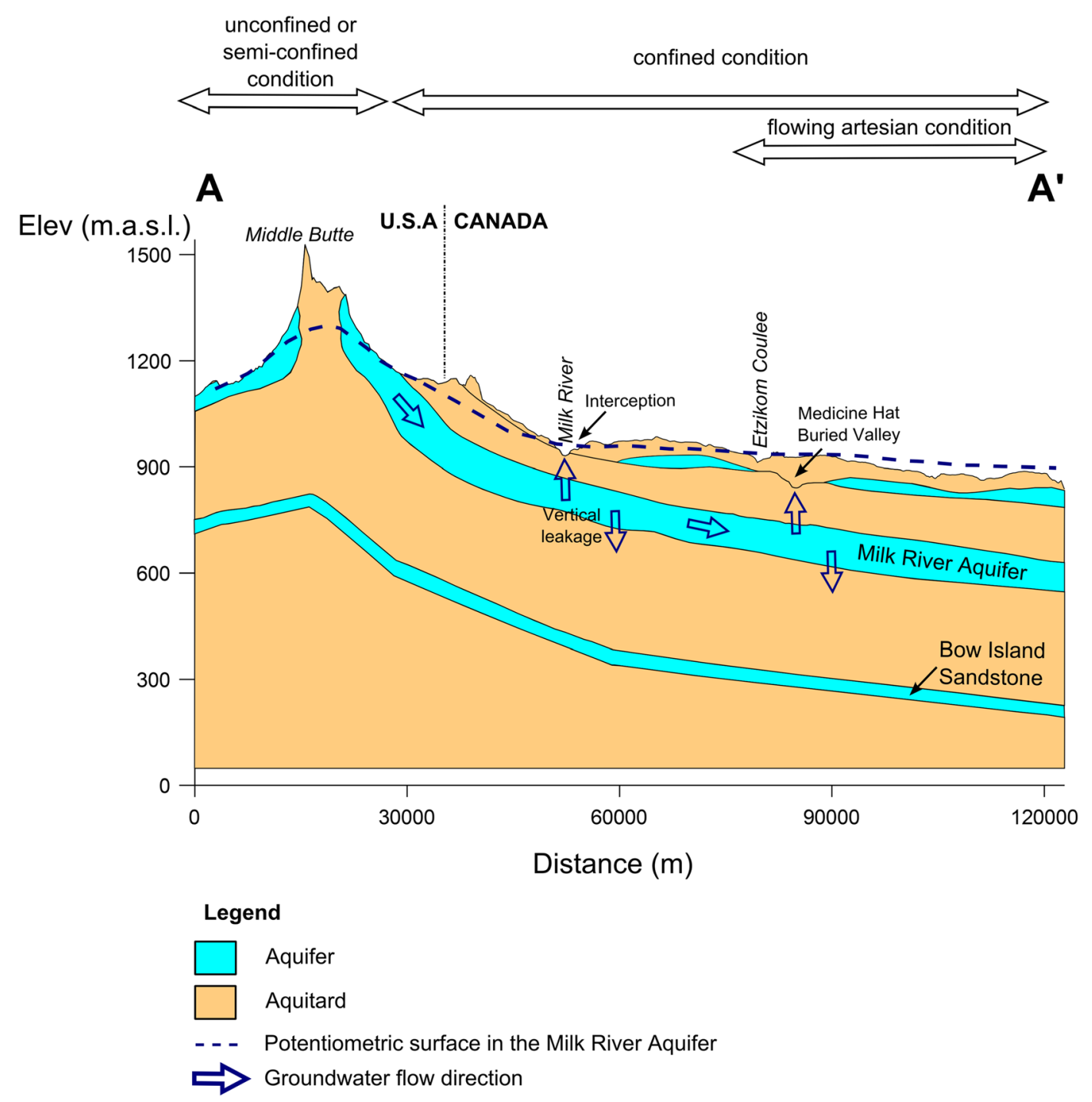

Fig. 13 Hydrogeological cross-section of the MRA located along a flow line. Location of the cross-section is shown on Fig. 2

could be supported by the buried valley located underneath the present-day Milk River.The conceptual geochemical cross-section (Fig. 14) was produced from Figs. 9b and 11 and illustrates the evolution of the groundwater from the MRA down-gradient.

Modern water (defined by high tritium concentrations) is not only found in the outcrop areas near the border but also west of the Sweet Grass Arch. This suggests that the entire outcrop belt around the Sweet Grass Arch could act as a recharge area of the MRA. Furthermore, hydrographs of three monitoring wells of the MRA located in the outcrop branches in Montana (GWIC Id 88838, 45363 and 90371) show that water level fluctuations follow the meteorological changes, thus supporting the assumption that they are located in the recharge area. This assumption differs from previous work where the emphasis was generally placed on the Sweet Grass Hills as the main recharge area (Meyboom 1960; Domenico and Robbins 1985).
There is no ${ }^{14} \mathrm{C}$ in the waters of the MRA beyond the Milk River. This suggests that a major part of the groundwater flow is intercepted by the Milk River. Therefore, the remaining flux and the hydraulic gradient are low beyond the river, resulting in low groundwater velocity and high groundwater residence time as indicated by isotopic tracers. In Montana, the disappearance of ${ }^{14} \mathrm{C}$ is simply due to the decay along the flowpath. South-west of the Sweet Grass Arch in Montana, the decrease in ${ }^{14} \mathrm{C}$ values is less pronounced. This observation is consistent with the low chlorine concentration, the high transmissivity and the prevalence of little-evolved water types containing sulfates defining this area. These characteristics indicate that the groundwater flow is active in this part of the study area.

North of the Milk River and in the south-eastern part of the study area, old to very old waters (up to $2 \mathrm{Ma}$ ) are found, as shown by ${ }^{36} \mathrm{Cl}$ data. The groundwater flow is low and water types are more evolved. Berkenpas (1991) provided hydrogeological evidence south-east of Lake Pakowki and 


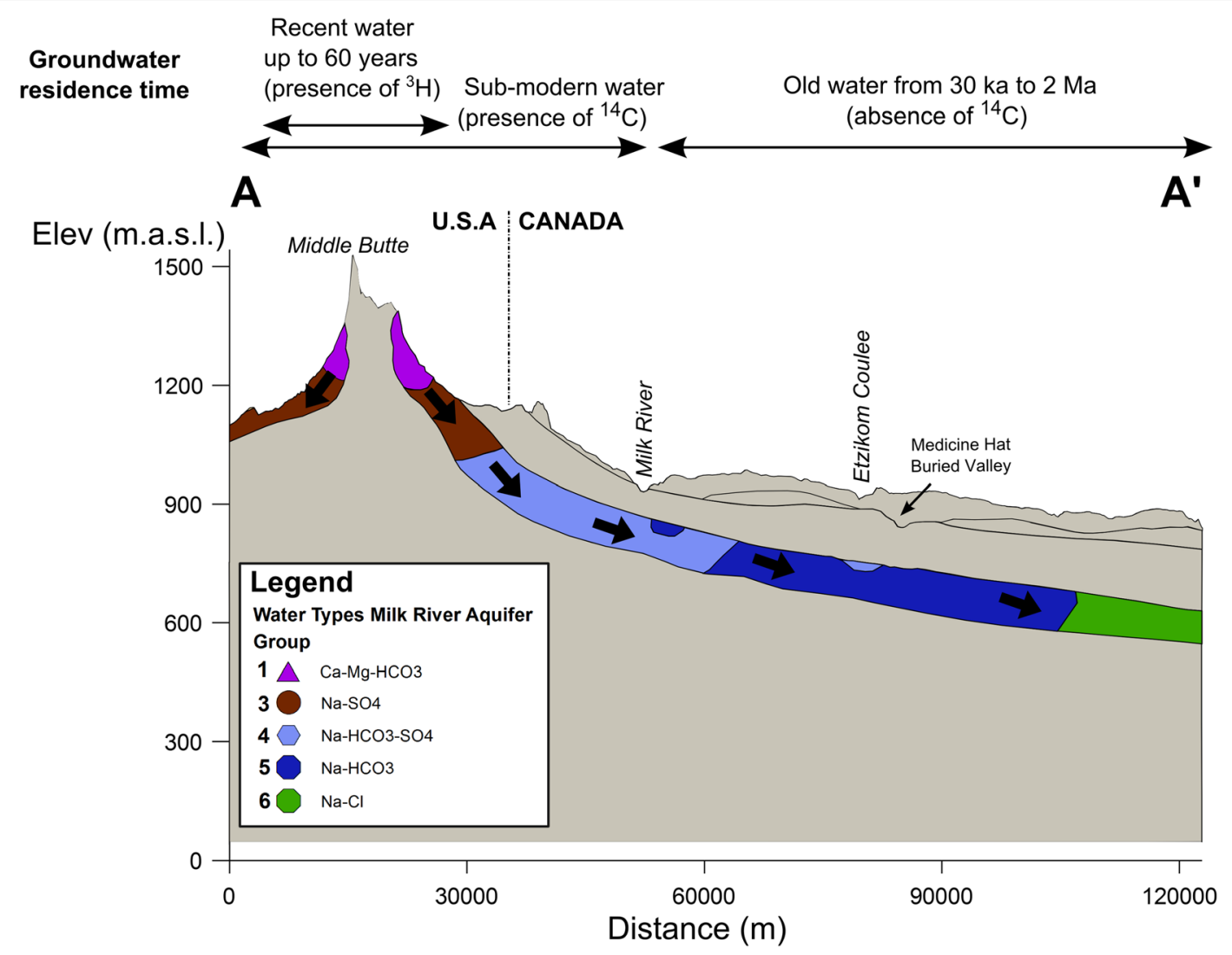

Fig. 14 Geochemical conceptual model of the MRA represented by a schematic cross-section from the Sweet Grass Hills (Montana, USA) to the north-eastern limit of the MRA in Alberta, Canada. Water types are described accordingly with the spatial distribution on Fig. 9b. Flow directions within the MRA are represented by black arrows. The groundwater residence time is indicated based on the isotopic data $(k a$ is thousand years and $M a$ is million years) south of Manyberries, indicating that a region with a no flow or very low groundwater flow (hydrostatic conditions) existed in the area. The evolved water type $\left(\mathrm{Na}-\mathrm{HCO}_{3}\right)$ and the old water residence time in this area are consistent with this statement.

Figure 15 presents a plan view of the conceptual model of the MRA in which the areas of active recharge, active flow, low flow and discharge are delineated within the natural extent of the MRA. The area of active recharge corresponds to the presence of tritium in the MRA waters and is limited to the outcrop/subcrop areas of the MRA. Some groundwater may come from the topographic highs (Cypress Hills, Bears Paw Mountains). The area of active flow corresponds to the presence of ${ }^{14} \mathrm{C}$ and is located beyond the recharge area and upgradient of the Milk River. The area of low flow is present in the major part of the study area and is defined by the absence of ${ }^{14} \mathrm{C}$ and old waters presenting evolved water types. Except for the Milk River, there is no natural direct discharge zone, but discharge or outflow may occur through vertical leakage along the buried valleys and through the underlying aquitards of the Colorado Group as shown by the vertical hydraulic gradient (Fig. 8). The vertical leakage could also be enhanced in the north-western part of the study area, due to the gradual thinning of the Pakowki Formation (Swanick 1982; Pétré et al. 2015). In Montana, the potentiometric map indicates that the same mechanism is likely to occur as an upward flow from the Eagle Formation towards the Claggett and Judith River formations and into the surficial sediments of the Big Sandy Creek area. Besides, the presence of the Bears Paw Mountains in the south-east corner of the study area would prevent the groundwater flow to progress any further east and therefore incites the vertical leakage.

\section{Groundwater budget}

Once the flow system and the relationship between the hydrostratigraphic units are well defined according to hydrogeological and geochemical data, the last step in building the conceptual model is the preparation of a water budget. As the concerns regarding the aquifer depletion are mostly present in southern Alberta, a detailed groundwater budget in zone 1 (Fig. 12) is proposed (Fig. 16).

The water balance equation states that under steady condition: outflow - inflow $=$ change in storage (Anderson and Woessner 1992). The source of water to the aquifer system corresponds to the groundwater recharge from precipitation. 


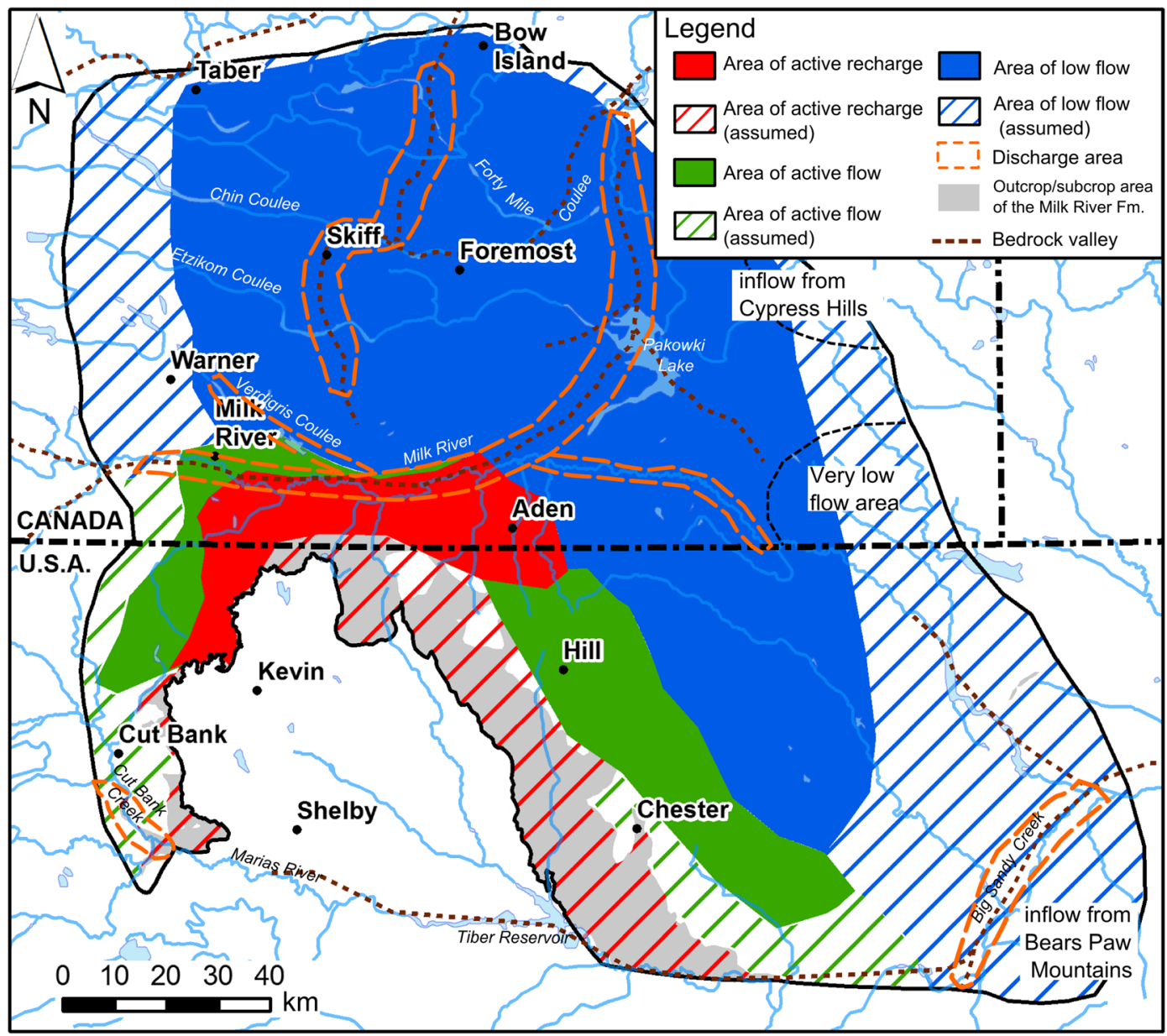

Fig. 15 Plan view of the conceptual model of the MRA

Outflows include the part of the flow intercepted by the Milk River, the vertical leakage through overlying and underlying aquitards, pumping wells and flowing wells. The components of the groundwater budget have been estimated on a crosssection representing the annual water budget in zone 1 (Fig. 16a). A distinction is made between zone 1a and zone $1 \mathrm{~b}$ since the remaining flow out of zone $1 \mathrm{a}$ (part of flow which is not intercepted by the Milk River) constitutes the inflow of zone $1 \mathrm{~b}$. For consistency, components are expressed as a water thickness equivalent uniformly distributed on the total surface of the considered area (i.e. $1.45 \times 10^{10} \mathrm{~m}^{2}$ ). The values of the components are given in the section 'Hydrogeological setting'. The vertical leakage fluxes directed upwards and downwards have been estimated from the vertical hydraulic gradient (Fig. 8). The magnitude of the vertical leakage through the aquitards and along the bedrock valleys depends on the vertical hydraulic conductivity of the units surrounding the MRA. These parameters are not well known over the regional study area, hence the large range of values. The amount of groundwater stored in the MRA was obtained by the product of the volume between the top of the aquifer and the potentiometric surface by the storage coefficient $\left(3 \times 10^{-4}\right.$;
Meyboom 1960). This calculation has only been made where the potentiometric surface was defined in zone $1 \mathrm{~b}$ (a surface of $7.43 \times 10^{9} \mathrm{~m}^{2}$ ). The mean distance between the potentiometric surface and the top of the MRA is about $171 \mathrm{~m}$. The total amount of water stored in the MRA is about $380 \times 10^{6} \mathrm{~m}^{3}$. Figure $16 \mathrm{~b}$ shows a comparison between the different parameters, and the effective recharge in zone 1a is taken as a reference. As shown on Fig. 16a, most of the recharge is intercepted by the Milk River. The remaining flux transmitted beyond the Milk River is only about $0.4 \times 10^{6} \mathrm{~m}^{3} / \mathrm{y}(0.03 \mathrm{~mm} /$ y), i.e. up to ten times smaller than the sum of the outflows in zone $1 \mathrm{~b}\left(3.5 \times 10^{6} \mathrm{~m}^{3} / \mathrm{y}\right.$ or $0.24 \mathrm{~mm} / \mathrm{y}$ using maximum values). The human stress on the aquifer resource (through pumping and flowing wells) is the main outflow contribution north of the Milk River. Indeed, the location of the main groundwater users in southern Alberta is precisely downgradient the Milk River (zone 1b), explaining the water budget deficit in this area. It is clear that given the very low inflow in zone $1 \mathrm{~b}$, the groundwater extracted from the aquifer mostly comes from storage, indicating a depletion of the MRA following the definition from Konikow and Kendy (2005). The situation can also be described as groundwater mining since 


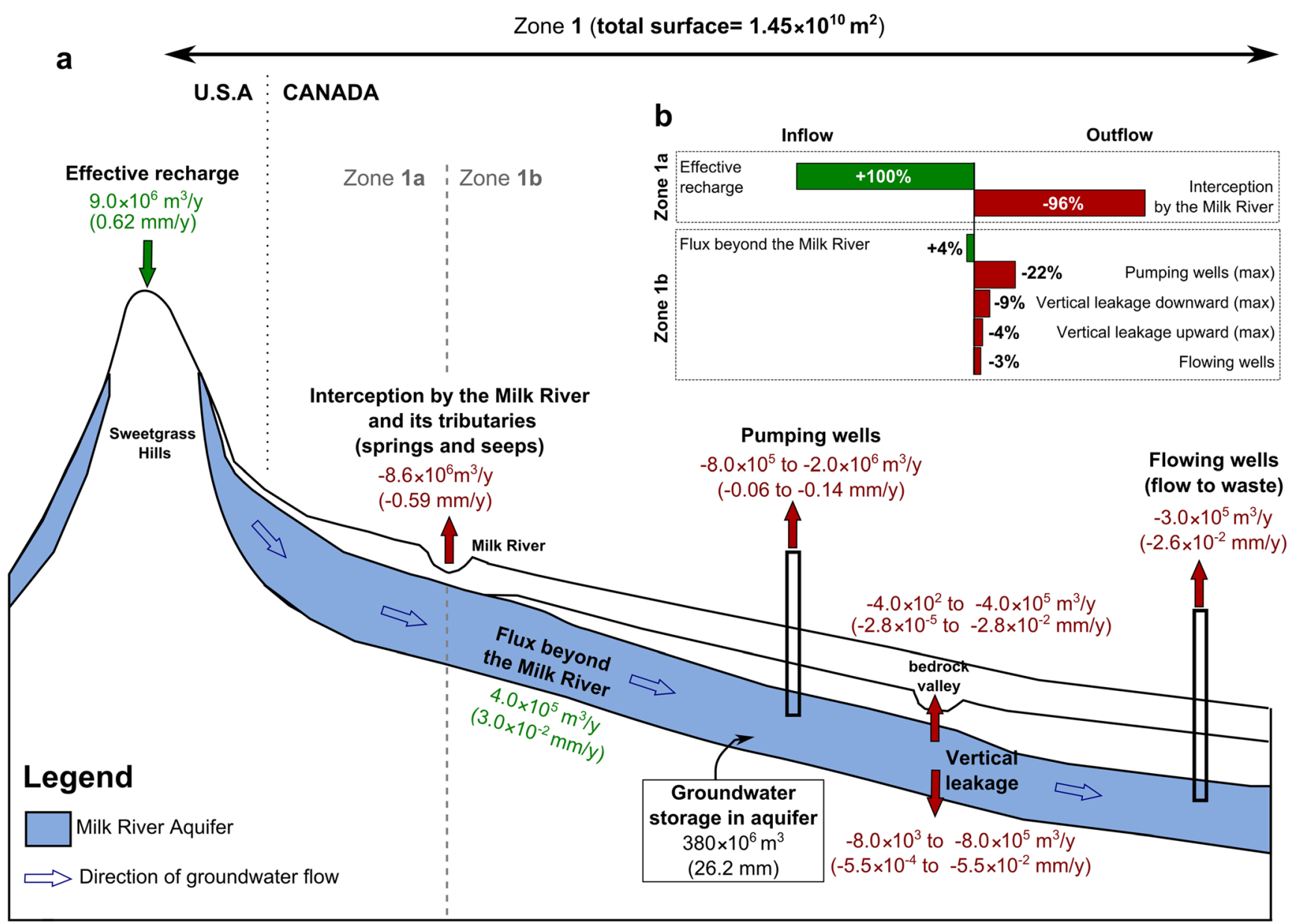

Fig. 16 a Groundwater budget in zone 1 (see location on Fig. 12). The recharge located south of the Milk River (zone 1a) is mostly intercepted by the Milk River as the water flows down-gradient. The remaining flux beyond the Milk River corresponds to the inflow in zone $1 b . \mathbf{b}$ Comparison of the components of the budget which are in deficit in zone $1 \mathrm{~b}$. The reference of the scaling is taken from the recharge $(100 \%)$ exploitation of groundwater far exceeds groundwater renewal (Custodio 2002). Moreover, previous studies (Meyboom 1960; AGRA Earth and Environmental 1998; HCL consultants 2004) even estimated that exploitable reserve of the MRA may last less than 200 years in southern Alberta. However, the full implications of the potential duration of exploitation of the resource will not be discussed further as they merit to be explored with a numerical model which constitutes the next stage in the transboundary study of the MRA.

\section{Conclusion}

Hydrogeological and geochemical data on both sides of the Canada-USA border were gathered to produce the first transboundary conceptual model of the MRA. Compilation of historical studies and new field data contributed to expanding our understanding of the hydrogeology of the aquifer in northern Montana and southern Alberta. There is a clear delineation of the hydrogeological extent of the MRA and its three constituting sub-systems following the natural boundaries of the aquifer instead of the jurisdictional boundaries, as was done in previous studies. The eastern and western transboundary flowpaths from Montana into Alberta were identified and quantified. The fluxes from the Sweet Grass Hills and the Cut Bank area to the south in Montana were defined. The definition of the water types on both sides of the international border showed the continuity of the geochemical water types and the processes involved in the aquifer. The isotopic data $\left({ }^{3} \mathrm{H}\right.$, ${ }^{14} \mathrm{C}$ and ${ }^{36} \mathrm{Cl}$ ) in Montana and Alberta showed that the entire outcrop belt around the Sweet Grass Arch corresponds to an area of recharge for the MRA. Changes in the lateral hydraulic gradient south and north of the Milk River suggest that the river intercepts a large component of the groundwater flowing north through the MRA. The study defined areas of active and low to very low groundwater flow. The discharge mechanism of the aquifer through the buried valleys both in Alberta and Montana was highlighted. The study also assessed historic and current groundwater uses in the MRA and proposed an aquifer-scale water budget. Overall, the MRA is not significantly renewed; 
with the exception of the recharge area it corresponds to a fossil resource. This conceptual model is a major component of the transboundary study of the MRA. Along with the previous unified geological model, it will form the basis for the future development of a numerical 3D groundwater flow model of the aquifer. The mathematical model will be used to test the conceptual model and to propose the best possible uses of this valuable resource that is shared by Canada and the United States of America. It is expected that the building of this conceptual model of the transboundary nature of the MRA will provide the knowledge and the tools as mechanisms for transboundary cooperation and shared management between the two countries.

Acknowledgements We thank the Groundwater Geoscience Program of the Geological Survey of Canada for financial support of this work within MiRTAP (Milk River Transboundary Aquifer Project). We are grateful to Tim Romanow, Sandy Riemersma, Mary Lupwayi and John Ross from the Milk River Watershed Council Canada, as well as Daryl Jaques (Agriculture and Agri-Food Canada) and Clarisse DeschênesRancourt (INRS-ETE) for their support during the fieldwork in Alberta. We are also thankful to Kyle Blasch, Jill Frankforter, Joanna Thamke and Lori Tuck from the USGS office in Helena, Montana, for their precious help during the Montana field campaign. We thank Ryan Davison (Davison Environmental Consulting) for the complementary fieldwork in Alberta. Thanks are due to Dave Matz (County of Forty Mile, Alberta) for giving permission to use unpublished inorganic chemistry data originating from the 2006 Milk River Aquifer pump test program and the Groundwater Monitoring Project (joint project with Agriculture and Agrifood Canada/PFRA and Alberta Environment). Jeff Gutsell (Alberta Environment and Parks), Steve Grasby (GSC-Calgary), Tony Lemay and Dan Palombi (Alberta Energy Regulator, Edmonton) are also thanked for their constructive comments on an early version of this paper. This is Earth Sciences Sector contribution No. 20150304.

\section{Appendix}

The following standard equation was used to obtain ages from

${ }^{36} \mathrm{Cl} / \mathrm{Cl}$ ratios (Bentley et al. 1986).

$t=-\frac{1}{\lambda_{36}} \ln \frac{R-R_{\mathrm{se}}}{R_{\mathrm{o}}-R_{\mathrm{se}}}$

Where $t$ is time (s), $\lambda_{36}$ is the ${ }^{36} \mathrm{Cl}$ decay constant $(2.3 \times$ $\left.10^{-6} / \mathrm{a}\right), R$ is the measured ${ }^{36} \mathrm{Cl} / \mathrm{Cl}$ ratio, $R_{0}$ the initial ${ }^{36} \mathrm{Cl} / \mathrm{Cl}$ ratio and $R_{\mathrm{se}}$ is the secular equilibrium ${ }^{36} \mathrm{Cl} / \mathrm{Cl}$ ratio.

Open Access This article is distributed under the terms of the Creative Commons Attribution 4.0 International License (http:// creativecommons.org/licenses/by/4.0/), which permits unrestricted use, distribution, and reproduction in any medium, provided you give appropriate credit to the original author(s) and the source, provide a link to the Creative Commons license, and indicate if changes were made.

\section{References}

AGRA Earth and Environmental (1998) Evaluation of depletion of the Milk River aquifer. AGRA Earth \& Environmental, Edmonton

Alberta Environment and Parks (2015) Groundwater observation well network. http://esrd.alberta.ca/water/programs-andservices/groundwater/groundwater-observation-wellnetwork/default.aspx. Accessed March 2015

Alberta Innovates Technology Futures (2010) Milk River Aquifer hydrogeology report. Prepared for the Geological Survey of Canada, Quebec Division, Quebec City, QB

Anderson MP, Woessner WW (1992) Applied groundwater modeling: simulation of flow and advective transport. Gulf, Houston, TX

Anna LO (2011) Effects of groundwater flow on the distribution of biogenic gas in parts of the northern Great Plains of Canada and United States. US Geol Surv Sci Invest Rep 2010-5251

Bentley HW, Phillips FM, Davis SN (1986) Chlorine-36 in the terrestrial environment. Handb Environ Isot Geochem 2:427-480

Berkenpas PG (1991) The Milk River shallow gas pool: role of the updip water trap and connate water in gas production from the pool. Society of Petroleum Engineers, Richardson, TX

Bethke CM, Johnson TM (2002) Paradox of groundwater age: correction $^{1}$. Geology 30:385-388

Borneuf DM (1974) Hydrogeological map of the Foremost area, Alberta: NTS mapsheets 72E. Alberta Geological Survey, Map 110, AGS, Edmonton, $\mathrm{AB}$

Borneuf DM (1976) Hydrogeology of the foremost area. Earth sciences report 1974-04, Alberta Research Council, Edmonton, AB

Bredehoeft J (2005) The conceptualization model problem: surprise. Hydrogeol J 13:37-46

Chen Z, Shuai Y, Wang N (2015) A reassessment of gas resources in selected Upper Cretaceous biogenic gas accumulations in southeastern Alberta and southwestern Saskatchewan, Canada. Bull Can Petrol Geol 63:5-19. doi:10.2113/gscpgbull.63.1.5

Clark ID, Fritz P (1997) Environmental isotopes in hydrogeology, 1st edn. CRC, Boca Raton, FL

Climate Canada (2015) Canadian Climate Normals. 1981-2010 Climate normals and averages. http://climate.weather.gc.ca/climate normals/index_e.html. Accessed 12 Jan 2015

Collier AJ (1930) Contributions to economic geology (short papers and preliminary reports), 1929, part II: mineral fuels. In: The KevinSunburst oil field and other possibilities of oil and gas in the Sweetgrass Arch, Montana. US Geol Surv Bull 812-B

Colton RB, Lemke RW, Lindvall RM (1961) Glacial map of Montana east of the Rocky Mountains. US Geol Surv IMAP 327, Scale 1:500,000

Cummings DI, Russell HA, Sharpe DR, Fisher TG (2012) Buried-valley aquifers in the Canadian Prairies: geology, hydrogeology, and origin. Can J Earth Sci 49:987-1004

Custodio E (2002) Aquifer overexploitation: what does it mean? Hydrogeol J 10:254-277

Domenico PA, Robbins GA (1985) The displacement of connate water from aquifers. Geol Soc Am Bull. doi:10.1130/0016-7606(1985)962.0.CO;2

Dormaar JF (2003) Sweetgrass Hills: a natural and cultural history. Lethbridge Historical Society, Lethbridge, AB

Dormaar JF (2010) The Alberta Stretch of the Milk River and the Mystique of its surrounding landscape. Lethbridge Historical Society, Lethbridge, AB

Dowling DB (1917) Southern plains of Alberta. Geological Survey of Canada, "A" Series Map 187A, 1917; 1 sheet, doi:10.4095/106740

Drimmie RJ, Aravena R, Wassenaar LI et al (1991) Radiocarbon and stable isotopes in water and dissolved constituents, Milk River aquifer, Alberta, Canada. Appl Geochem 6:381-392. doi:10.1016/08832927(91)90038-Q 
Environment and Climate Change Canada (2012) Water availability in Canada. http://www.ec.gc.ca/indicateurs-indicators/default. asp?lang=en\&n=1B1433B4-1. Accessed 4 May 2015

Fabryka-Martin J, Whittemore DO, Davis SN et al (1991) Geochemistry of halogens in the Milk River aquifer, Alberta, Canada. Appl Geochem 6:447-464. doi:10.1016/0883-2927(91)90044-P

Farvolden RN, Meneley WA, Lebreton EG et al (1963) Early contributions to the groundwater hydrology of Alberta. Alberta Res Counc Bull 12:123

Fröhlich K (2013) Milk river aquifer, Alberta, Canada - A case study. In: Suckow, A, Aggarwal PK, Araguás LA (eds) Isotope methods for dating old groundwater. International Atomic Energy Agency, Vienna, Austria, p 259-272

Fröhlich K, Ivanovich M, Hendry MJ et al (1991) Application of isotopic methods to dating of very old groundwaters: Milk River aquifer, Alberta, Canada. Appl Geochem 6:465-472. doi:10.1016/08832927(91)90045-Q

Fullerton DS, Colton RB (1986) Stratigraphy and correlation of the glacial deposits on the Montana Plains. Quat Sci Rev 5:69-82. doi:10.1016/0277-3791(86)90176-9

GIN (2015) Groundwater information network. Natural Resources Canada. http://gin.gw-info.net. Accessed 21 Dec 2015

Golder Associates L (2004) Development of a management/protection plan for the Whisky Valley Aquifer, County of Warner, Alberta. Report submitted to the Milk River West Water Users Co-op, Milk River, AB

Government of Alberta (2006) Water conservation and allocation guideline for oil field injection. Government of Alberta, Edmonton, AB, $64 \mathrm{pp}$

Grasby SE, Betcher R, Maathuis H, Wozniak P (2014) Plains hydrogeological region. In: Rivera A (ed) Canada's groundwater resources. Fitzhenry and Whiteside, Markham, ON, pp 358-413

GWIC (2015) Home page. GWIC, MBMG, Montana Tech, University of Montana, Butte, MT. http://mbmggwic.mtech.edu/. Accessed 21 Dec 2015

HCL Consultants (2004) County of Forty Mile no. 8, parts of the South Saskatchewan River and Missouri River Basins: regional groundwater assessment, Tp 001 to $013, \mathrm{R} 05$ to 14 , W4M. HCL, Edmonton, $\mathrm{AB}$

HCL Consultants (2007) Municipal district of Taber, part of the South Saskatchewan River Basin: regional groundwater assessment, parts of Tp 007 to 015, R 12 to 20, W4M, HCL, Edmonton, AB

Hendry MJ, Buckland GD (1990) Causes of soil salinization: 1. a basin in southern Alberta, Canada. Ground Water 28:385-393. doi:10.1111 j.1745-6584.1990.tb02268.x

Hendry MJ, Schwartz FW (1988) An alternative view on the origin of chemical and isotopic patterns in groundwater from the Milk River Aquifer, Canada. Water Resour Res 24:1747-1763. doi:10.1029 /WR024i010p01747

Hendry MJ, Schwartz FW (1990) The chemical evolution of ground water in the Milk River Aquifer, Canada. Ground Water 28:253261. doi:10.1111/j.1745-6584.1990.tb02253.x

Hendry J, Schwartz FW, Robertson C (1991) Hydrogeology and hydrochemistry of the Milk River aquifer system, Alberta, Canada: a review. Appl Geochem 6:369-380. doi:10.1016/08832927(91)90037-P

Huntoon PW (1985) Rejection of recharge water from Madison Aquifer along eastern perimeter of Bighorn Artesian Basin, Wyoming. Groundwater 23:345-353

IGRAC (2015) Transboundary aquifer of the world 2015. Special edition for the 7th World Water Forum 2015. International Groundwater Resources Assessment Center, Delft, The Netherlands. http://www. un-igrac.org/downloads. Accessed June 2016

Ivanovich M, Fröhlich K, Hendry MJ (1991) Dating very old groundwater, Milk River aquifer, Alberta, Canada. Appl Geochem 6:367-475

Konikow LF, Kendy E (2005) Groundwater depletion: a global problem. Hydrogeol J 13:317-320
Kresik N, Mikszewski A (2012) Hydrogeological conceptual site models: data analysis and visualization. CRC, Boca Raton, FL

Levings GW (1981) Selected drill-stem-test data from the Northern Great Plains area of Montana. US Geol Surv Open-File Rep 81-326, scale $1: 1,000,000$

Levings GW (1982a) Potentiometric-surface map of water in the Eagle Sandstone and equivalent units in the Northern Great Plains area of Montana. US Geol Surv Open-File Rep 82-565, scale 1:1,000,000

Levings GW (1982b) Potentiometric-surface map of water in the Judith River Formation in the Northern Great Plains area of Montana. US Geol Surv Open-File Rep 82-562, scale 1:1,000,000

Lies H, Letourneau J (1995) Numerical modelling of the hydrodynamically trapped milk river gas field, Western Canada. J Can Pet Technol 34(10)

Lopez DA (2002) Geologic map of the Lonesome Lake 30' x 60' quadrangle, north-central Montana. Montana Bur Mines Geol Open-File Rep 446, scale 1:100,000

MacCulloch G, Wagner-Watchel J (2010) Milk River Main Channel: channel losses and gains assessment, field study 2007. Preliminary report, Meteorological Service of Canada, Water Survey Division, Calgary, $\mathrm{AB}$

MBOGC (2015) MBOGC's online oil and gas information system. MBOGC, Dept. of Natural Resources and Conservation, Helena, MT. http://bogc.dnrc.mt.gov/WebApps/DataMiner/MontanaMap. aspx. Accessed 18 Dec 2015

Meyboom P (1960) Geology and groundwater resources of the Milk River sandstone in southern Alberta. Research Council of Alberta, Edmonton, $\mathrm{AB}$

Milk River Watershed Council Canada (2008) Milk river state of the watershed report 2008, Milk River Watershed Council Canada, Milk River, Alberta, p 155

Milk River Watershed Council Canada (2011) Synoptic groundwater quality survey: data file. Milk River Watershed Council Canada, Milk River, AB, Excel Spreadsheet

NOAA (2015) Data tools: 1981-2010 normals. NOAA, National Centers for Environmental Information, Washington, DC. http://www.ncdc. noaa.gov/cdo-web/datatools/normals. Accessed 12 Jan 2015

Nolte E, Krauthan P, Korschinek G et al (1991) Measurements and interpretations of ${ }^{36} \mathrm{Cl}$ in groundwater, Milk River aquifer, Alberta, Canada. Appl Geochem 6:435-445. doi:10.1016/0883-2927(91 90043-O

Norbeck P M (2006) Sunburst water-supply renovation: April 2006 project report to the Montana Department of Natural Resources and Conservation. Montana Bur Mines Geol Open-File Rep 548

Pétré M-A, Rivera A (2015) A synthesis of knowledge of the Milk River Transboundary Aquifer (Alberta, Canada - Montana, USA). Geol Surv Canada Open File 7654, 109 pp. doi:10.4095/295754

Pétré M-A, Rivera A, Lefebvre R (2015) Three-dimensional unified geological model of the Milk River Transboundary Aquifer (Alberta, Canada - Montana, USA). Can J Earth Sci 52:96-111. doi:10.1139 /cjes-2014-0079

Phillips FM, Bentley HW, Davis SN et al (1986) Chlorine 36 dating of very old groundwater: 2. Milk River Aquifer, Alberta, Canada. Water Resour Res 22:2003-2016. doi:10.1029/WR022i013p02003

Piper AM (1944) A graphic procedure in the geochemical interpretation of water-analyses. Trans Am Geophys Union 25:914-928

Printz J (2004) Milk River Aquifer reclamation and conservation program 1999-2004 summary report. Agriculture and Agri-Food CanadaPrairie Farm Rehabilitation Administration, Medicine Hat, AB

Rehm BW, Moran SR, Groenewold GH (1982) Natural groundwater recharge in an upland area of central North Dakota, USA. J Hydrol 59(3):293-314

Rice DD, Claypool GE (1981) Generation, accumulation, and resource potential of biogenic gas. AAPG Bull 65(1):5-25 
Rivera A(2011) Groundwater program Newsletter, vol 5, no. 1. Gov ofCanada, Ottawa. doi:10.4095/290226. http://ftp2.cits.rncan.gc.ca/pub/geott/ess pubs/290/290226/gwpn_v5.1_e.pdf. Accessed 18 Dec 2015

Robertson C (1988) Potential impact of subsurface irrigation return flow on a portion of the Milk River and Milk River Aquifer in southern Alberta. University Of Alberta, Edmonton, $\mathrm{AB}$

Rushton KR, Eilers VHM, Carter RC (2006) Improved soil moisture balance methodology for recharge estimation. J Hydrol 318:379399. doi:10.1016/j.jhydrol.2005.06.022

Schwartz FW, Muehlenbachs K (1979) Isotope and ion geochemistry of groundwaters in the Milk River Aquifer, Alberta. Water Resour Res 15:259-268. doi:10.1029/WR015i002p00259

Schwartz FW, Muehlenbachs K, Chorley DW (1981) Flow-system controls of the chemical evolution of groundwater. Dev Water Sci 16:225-243

Sosiak AJ, Branch AWS (1997) Pakowki Lake Water Quality Study (1996). Water Sciences Branch, Water Management Division, Natural Resources Service, Edmonton, AB

Stantec (2002) Regional groundwater assessment of potable groundwater in county of Warner no. 5, Alberta. County of Warner no. 5, Warner, AB

Stuiver M, Polach HA (1977) Discussion: reporting of C-14 data. Radiocarbon 19:355-363

Swanick GB (1982) The hydrochemistry and age of the water in the Milk River aquifer, Alberta, Canada. MSc Thesis, The University of Arizona, USA
Swenson FA (1957) Geology and ground-water resources of the lower marias irrigation project. USGS Water Supply Paper, Montana, $1460-\mathrm{B}$

Tokarsky O (1974) Hydrogeology of the Lethbridge-Fernie area, Alberta. Alberta Geol Surv Earth Sci Rep 1974-01

Toth J, Corbet T (1986) Post-Paleocene evolution of regional groundwater flow-systems and their relation to petroleum accumulations, Taber area, southern Alberta, Canada. Bull Can Petrol Geol 34:339-363

Tuck LK (1993) Reconnaissance of geology and water resources along the north flank of the Sweet Grass Hills, north-central Montana. US Geol Surv Water Resour Invest Rep 93-4026, 68 pp

Wassenaar L, Aravena R, Hendry J, Fritz P (1991) Radiocarbon in dissolved organic carbon, a possible groundwater dating method: case studies from western Canada. Water Resour Res 27:1975-1986

Williams MY, Dyer WS (1930) Geology of southern Alberta and southwestern Saskatchewan. Geol Surv Canada, Memoir 163. doi:10.4095/100794

WozniakPRJ,GrasbySE,ChenZ(2011)PreliminaryanalysisoftheGICAlberta groundwater data: a prospective data source for regional scale aquifer assessment. Geol Surv Canada Open File 5573. doi:10.4095/289059

Zimmerman E (1967) Water resources of the Cut Bank area, Glacier and Toole counties, Montana. Montana Bur Mines Geol Bull 60, 37 pp 